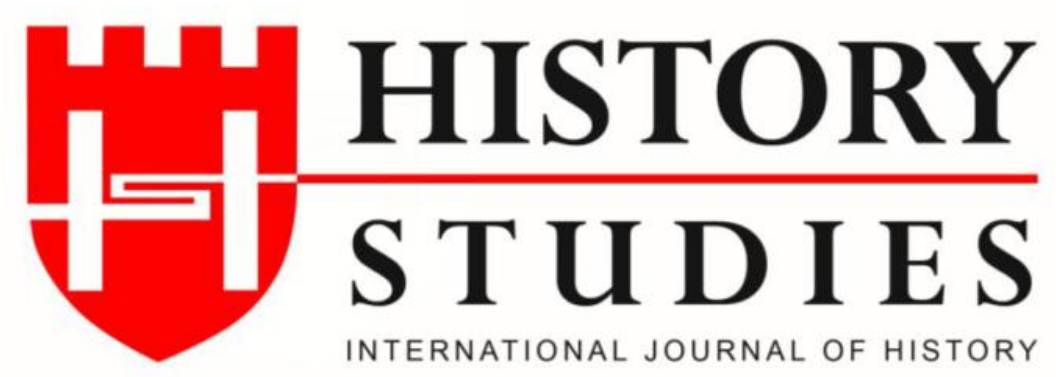

ISSN: 13094173 (Online) 1309 - 4688 (Print)

Volume 12 Issue 5, October 2020

DOI Number: 10.9737/hist.2020.940

Araştırma Makalesi

Makalenin Geliş Tarihi: 30.07.2020 Kabul Tarihi: 10.09.2020

Atıf Künyesi: Turgut İleri, “Millî Mücadele Döneminde Amasya ve Havalisinde Pontus Terörüne Karşı Alınan Tedbirler ve Kuva-yı Takibiye Kumandanlığının Kurulması Çalışmaları”, History Studies, 12/5, Ekim 2020, s. 2733-2760.

\title{
Millî Mücadele Döneminde Amasya ve Havalisinde Pontus Terörüne Karşı Alınan Tedbirler ve Kuva-yı Takibiye Kumandanlığının Kurulması Çalı̧̧maları
}

\section{The Precautions Against Pontus Terror and Attempts to Establish Headquarters of Kuva-yl} Takibiye in Amasya Province During the National Struggle Period

\author{
Dr. Turgut İleri \\ ORCID No: 0000-0003-2029-1354 \\ Amasya Üniversitesi
}

$\ddot{O} \mathbf{z}$

Millî Mücadele döneminde Batı Cephesinde Yunanlılarla savaş devam ederken batılı devletlerden aldıkları destekle Karadeniz Bölgesi'ndeki Hristiyan ahali, Pontus Devleti'ni yeniden canlandırmak üzere harekete geçmiştir. Kurdukları çetelerle Türk ahalinin yaşadığı köy, kasaba ve şehirlerde çeşitli yöntemler kullanarak saldırı ve eylemlerde bulunmuşlardır. Eylemler öldürme, gasp, yakma, tecavüz ve soygun şeklinde cereyan etmiştir. Bu eylemelere maruz kalan yerlerden biri de Amasya ve havalisi olmuştur. Rum çetelerinin Amasya mıntıkasındaki asayişi ve güvenliği tehdit edici faaliyetlerine karşı ciddi önlemler almak gerekmiştir.

Bölgede baş gösteren bozguncu hareketler hakkında hükümete, Erkan-1 Harbiye Umumi Riyaseti'ne, ilgili vekâletlere ve TBMM'ne bilgi verilmiştir. Bu girişimlerin ardından konu meclise getirilmiş, meclisin gizli oturumunda tartışmalar yapılmıştır. Mecliste yapılan müzakerelerin ardından bölgede asayişi sağlayacak ve Pontusçu faaliyetleri engelleyecek kararlar alınmıştır. Bu kapsamda, bir kısım jandarma birlikleri ile 15. Tümen ve 5. Kafkas Tümenine bağlı alaylardan bazıları bölgeye gönderilmiştir. Bununla yetinilmeyip karargâh merkezi Amasya olan Merkez Ordusu kurulmuştur. Alınan tedbirlerden diğerleri ise; bölgede sıkıyönetim ilanı, İstiklal Mahkemesinin kurulması, Rumların göç ettirilmesi, silahların toplanması, bir kısım güvenlik teşkilatlarının kurulması ile Amasya ve Havalisi Kuva-yı Takibiye Kumandanlığını kurma çalışmalarıdır. Bu çalışmada, Pontusçu Rumların bölgede yarattıkları bozguncu hareketlere karşı alınan tedbirler hakkında bilgi verilecektir.

Anahtar Kelimeler: Millî Mücadele, Amasya, Terör, Pontus, Merkez Ordusu 
Millı̂ Mücadele Döneminde Amasya ve Havalisinde Pontus Terörüne Karşı Alınan Tedbirler

\begin{abstract}
While the war going on with the Greek military forces in the western front, The Christian community started to establish the Pontus Greek State again in the Black sea Region with the support of the western countries. They raid villages, towns and cities where the Muslim people lived with the armed bands they established. These events involved murder, mug, arson, rape and robbery. These events also happened in Amasya province. Serious precautions had to be taken in Amasya province against these events which threatened the safety and security of the local people.

Then necessary information was given to the Government, Headquarters of Turkish Military forces, related ministries and Turkish Grand Assembly. After these attempts the issues was brought to the Turkish Grand Assembly and secret sessions were held there. After the discussions held in The Turkish Grand Assembly, some decisions were taken to establish the safety and security in the province to prevent the raids of the Pontus gangs. Some military forces such as 15 th division and 5th Caucasian were sent to the province. Then, the Central Army was established whose headquarters was in Amasya. The other precautions taken in the province were the declaration of martial law, establishment of Independence Courts, deportation of Greek people in the province, collection of guns from the Greek people, establishment of some security forces such as Kuva-y1 Takibiye Forces. In this study, some knowledge is given about the precautions taken in the province against the catalytic attempts of Pontus Greek gangs.
\end{abstract}

Keywords: National Struggle, Amasya, Terror, Pontus, Central Army.

\title{
Giriş
}

30 Ekim 1918 tarihinde Mondros Ateşkes Antlaşması'nın imzalanmasından sonra Birinci Dünya Savaşı'nın galibi devletler, Osmanlı Devleti yönetimine müdahale ederek egemenliğinde bulunan Anadolu topraklarını işgal girişimlerinde bulunmuşlardır. Savaşın galibi devletlerin bu girişimleri karşısında, merkezi hükümet haklarını ve egemenlik alanlarını savunma gücünü gösterememiştir. Merkezi yönetimin otoritesini önemli ölçüde kaybetmiş olması, yönetim boşluğunun doğmasına, beraberinde güvenlik ve asayişin bozulmasına yol açmıştır. Yaşanılan bu olumsuzlukları ortadan kaldırmak amacıyla 19 Mayıs 1919 tarihinde Mustafa Kemal Paşa Samsun'a çımış ve Millî Mücadele hareketini başlatmıştır. Yaklaşık üç yıl süren Millî Mücadele sırasında cephelerde başarı kazanılmasına ve her türlü tedbirlerin alınmasına rağmen güvenlik ve asayişin sağlanmasında ciddi sorunlar yaşanmıştır. TBMM'nin açılması ve ardından yeni hükümetin kurulması ile asayiş ve güvenlik öncelikle ele alınan konular arasında yer almıştır. Bu dönemde özellikle Rum ve Ermenilerin İtilaf Devletlerinden aldıkları destek ve yardımlar ile başlattıkları çetecilik faaliyetleri, genel asayişi bozma yanında Türk ahalinin yaşam hakkını ortadan kaldırmaya yönelik eylemler halini almıştır. Ermeniler Doğu ve Güney Anadolu'da, Rumlar İstanbul, İzmir ve çevresi ile Karadeniz Bölgesi vilayetlerinde terör faaliyetlerinde bulunmuşlardır. Ülkenin içinde bulunduğu durumu, Mustafa Kemal Paşa, Nutuk’ta;

“... memleketin her tarafinda Hristiyan azınlıklar gizli ve açıktan açı̆̆a kendi özel emel ve maksatlarını gerçekleştirmeye, devleti bir an önce çökertmeye çalışıyorlardı" 
sözleri ile ortaya koymuştur ${ }^{1}$. Benzer şekilde o günlerde özellikle Rumların Karadeniz Bölgesinde yarattı̆̆ rahatsızlıklar, çeşitli yollardan dile getirilmiş, durumun ciddiyeti bizzat Harbiye Nezaretine şifre ile bildirilmiştir. ${ }^{2}$ Bölgede yaşanılan sıkıntılar, güvenlik ve asayiş olaylarına ilişkin şikayetler nezarete gönderilen diğer bir şifrede özetlenmiş; Rumların Merzifon çevresinde yaptıkları hunharca eylemlerinden söz edilerek, insanlık dışı davranışların İtilaf Devletleri temsilcilerine bildirilmesi ve onlara bu konuda etki edilmesi istenmiştir. ${ }^{3}$

Söz konusu dönemde gayr-i Müslim unsurların ülkede güvenlik ve asayişi bozma, sürdürülen Millî Mücadele'yi engelleme faaliyetleri haylice fazladır. Bu durumu gözler önüne seren, anlatan ve açıklayan birçok bilgi, belge ve çalışma bulunmaktadır ${ }^{4}$. Yaşanan tüm bu olumsuzluklar karşısında TBMM, düzeni ve asayişi sağlamak, iç düzeni ve barışı kurmak, tüm tedhiş ve eşkıyalık olaylarını önlemek amacıyla tedbirler almak zorunda kalmıştır. Bu tedbirlerden en önemlilerinden birisi İstiklal Mahkemeleri'nin kuruluşuna vesile olacak, ülkede güvenlik ve asayişi sağlayacak, asker kaçakları, eşkıyalık ve casusluk gibi faaliyetleri önleyeceği düşünülen Hıyanet-i Vataniye Kanunu'dur. ${ }^{5}$ Adı geçen kanunun meclisin açılışından 2 gün sonra teklif edilmesi ve 6 gün sonra çıkarılmış olması durumun ciddiyetini ve aciliyetini göstermektedir. Bu konu üzerinde yapılan çalışmaların hemen hepsinde o günlerde ülkede genel güvenlik ve asayişin iyi olmadığına işaret edilmektedir. ${ }^{6}$ Durumun oldukça sıkıntılı bir hal alması üzerine başlangıçta 7 bölgede 8 adet İstiklal Mahkemesi kurulmuştur. ${ }^{7}$ Kurulan bu mahkemeler marifeti ile huzura, asayişe ve güvenliğe kastedenlerin cezalandırılması yoluna gidilmiştir.

Volume 12

Issue 5

October

2020

\footnotetext{
${ }^{1}$ Nutuk 1919-1927, Atatürk Araştırma Merkezi, Ankara 1995, s. 1.

2 Arşiv Belgeleriyle Rum Faaliyetleri (1918-1922), Cilt I, Genel Kurmay Basımevi, Ankara 2009, s.368. (Bu şifrelerden biri 7 Haziran 1919 tarihli olup, 9. Ordu Kıtaat Müfettişi Mustafa Kemal tarafından Havza'dan Harbiye Nezaret-i Celile'sine gönderilen şifredir. Bu şifrede; Amasya'ya bağlı Merzifon kazasında İngilizlerin, Rum ve Ermenilerden oluşan bir teşkilat oluşturmaya çalıştı̆̆ından, Merzifon Amerikan Koleji’ne ait eşya denilerek Samsun'dan muhtevası henüz bilinmeyen sandıklar dolusu sevkiyat yapıldığından ve Gümüşhacıköy kazasındaki Rumların eylemlerinden dolayı takibata uğratılmaması yolunda yine bir İngiliz zabitinin mahallin kaymakamına bildirimde bulunulduğundan söz edilmektedir. Şifrenin son kısmında, bu gelişmelere yönelik mahallin icabına göre tedbirlerin alınacağı ifade edilmiştir).

${ }^{3}$ Age, s.385

${ }^{4}$ Ermeni ve Rumların faaliyetlerini anlatan eserlerden bazıları; Pontus Meselesi, (Yay. Haz. Yılmaz Kurt), Ankara 1995; Pontus Meselesi, (Yay. Haz. Yusuf Gedikli), İstanbul 2002; Mesut Çapa, Pontus Meselesi Trabzon ve Giresun'da Millî Mücadele, Ankara 1993; Arşiv Belgeleriyle Rum Faaliyetleri (1918-1922), Cilt I, Genel Kurmay Basımevi, Ankara 2009; Arşiv Belgeleriyle Ermeni Faaliyetleri (1914-1918), Cilt II, Genel Kurmay Basımevi, Ankara 2005; Nuri Yazıc1, Milli Mücadelede (Canik Sancağında)Pontusçu Faaliyetler (1918-1922), Ankara 1989.

${ }^{5}$ Düstur, Üçüncü tertip, C. 1, s. 4.

${ }^{6}$ Salhadin Gök, "Birinci Dönem İstiklal Mahkemelerinin TBMM'de Yansımaları" İstiklal Mahkemeleri Sempozyumu, 10-11 Aralık 2015, Adlyaman, Atatürk Araştırma Merkezi, Ankara 2016, s.53-58; Istiklal Mahkemeleri, (Kanun, Gerekçe ve Genel Kurul Tutanakları), C. 1, T.B.M.M. Basın, Yayın ve Halkla İlişkiler Başkanlığı Basımevi, Ankara 2015, s. 1-3; A. Turan Alkan, İstiklal Mahkemeleri, Ağaç Yayıncılık, İstanbul 1993, s. 18-19; Rıza Zelyut, İstiklal Harbi'nin Hukuk Cephesi İstiklal Mahkemeleri (Meclis Tutanakları), I. Baskı, Kripto Basım Yayım Dağıtım, Ankara 2017, s. 27; Ergün Aybars, İstiklal Mahkemeleri 1920-1927, I. Bask1, İstanbul 1997, s.21-25. Bu çalışmalarda ülkede asayişin bozukluğundan, durumu firsat bilen askerlerin firar ettiklerinden, çetelerin kurulduğundan; bunların yağmacılık ve soygun faaliyetlerinde bulunduklarından, kısaca ülkede tam bir kaos ortamının hâkim olduğundan söz edilmektedir.

7 Turgut İleri, "Millî Mücadele Döneminde Amasya'da İstiklâl Mahkemesi Kurma Çalışmaları”, Tarih Yolunda Bir Ömür; Ergün Öz Akçura Armağanı, Ed. Ahmet Aksın-Yavuz Haykır-Filiz Yıldırım, Hiper yayın, C.II, I. Baskı, İstanbul 2019, s.403
} 
Amasya civarında da bu dönemde güvenliğin ve asayişin bozulmasında, kargaşa ortamının oluşmasında daha ziyade Rumların oluşturdukları Pontusçu faaliyetler dikkat çekmiştir. Bu nedenle bozguncu hareketleri önlemek için tedbirler alınmasına ihtiyaç duyulmuştur. Alınan tedbirlerden birisi bölgede İstiklal Mahkemelerinin kurulmasıdır. Bu kapsamda Mecliste yapılan tartışmalar sonunda, Samsun, Tokat ve Amasya'yı da içine alan bölgede 27 Temmuz 1922 tarihinde Amasya İstiklal Mahkemesi kurulmuştur. ${ }^{8} \mathrm{Bu}$ tarihten itibaren asayiş ve güvenliği ihlal edenler ile bozguncu eylemler içinde bulunanların yargılanmalarının burada yapılması kararlaştırılmıştır.

Millî Mücadele Döneminde, bölgedeki tüm bozguncu faaliyetlere yönelik alınan bu ilk tedbirlerin yanında başkaca tedbirlere de başvurulmuştur. Bunlar: Merkez Ordusunun kurulması, sıkıyönetim ilan edilmesi, Asayiş Mıntıkaları Teşkilatı'nın oluşturulması, Asayiş Bölüklerinin kurulması, Emniyet Teşkilatı ile Amasya ve Havalisi Kuva-yı Takibiye Kumandanlığının kurulmasıdır. Aşağıda bu kapsamda yapılan düzenlemeler ve alınan tedbirler hakkında ayrıntılı bilgi verilecektir.

\section{1- Amasya ve Havalisinde Güvenlik ve Asayiş Sorunu \\ 1.1- Pontus Meselesinin Ortaya Çıkışı}

Yukarıda kısaca bahsedildiği üzere gerek Birinci Dünya Savaşı sırasında gerekse mütarekenin yürürlüğe konmasından sonra Anadolu'nun birçok vilayetinde olduğu gibi, Amasya'nın da içinde yer aldığı Karadeniz Bölgesi'nde de asayiş ve güvenlik sorunları ile karşılaşılmıştır. Birinci Dünya Savaşında alınan yenilgi beraberinde tüm ülkede otorite boşluğu yaratmış, bu durum aynı zamanda iç güvenliği tehdit eder hale gelmiş ve toplum hayatını ciddi manada etkilemiştir. ${ }^{9}$ Bölgedeki asayiş sorunu İtilaf Devletleri tarafından farklı değerlendirilmiş; asayişi bozanların yerel Türk unsurlar olduğu kanaatini taşımışlardır. Nitekim esas amacı başka olmakla beraber asayişi temin için Mustafa Kemal Paşa, resmi görevle Samsun'a gönderilmiştir. Bölgede bir asayiş sorununun olduğu muhakkaktır. Ancak, güvenliği tehdit edenler ile asayişi bozanların Türk unsurlar değil, ağırlıklı olarak Rumlar ve onların örgütlü hareketleri olduğu görülmüştür. Konu Mustafa Kemal Paşa tarafından ciddi manada önemsenmiş, henüz Samsun'a varmadan yerel yönetici ve komutanlardan bilgi almaya çalışmıştır. Bu amaçla Sivas Valiliğine, Canik (Samsun) Mutasarrıflığına ve III. Kolordu Komutanlığına şifre yazı gönderilmiş; yazıda bölgede faaliyette bulunan eşkıya çetelerinin Rum ve Ermeniler olduğunun bilindiği, bunların sayıları ile ne tür silah kullandıkları, çetelerin içerden mi yoksa dışardan $\mathrm{m}$ geldiklerinin tespit edilerek bilgi verilmesi istenmiştir. ${ }^{10}$ Mustafa Kemal Paşa Samsun'a geldikten sonra bölge ile ilgili gözlemlerini 22 Mayıs 1919 tarihinde rapor halinde Sadaret makamına göndermiştir. Raporda, Samsun livasındaki bozguncu hareketlerin Rumlar tarafından başlatıldığı ve Rusların da eylemcilere destek verdiklerinden söz edilmiş, bölgedeki Rumların Müslüman ahaliye sıkıntı veren hareketlerinden ve siyasi emellerinden vazgeçmeleri halinde asayişin düzeleceğine işaret edilmiştir. ${ }^{11}$ Benzer şekilde durumu özetleyen ve dikkat çekmeyi amaçlayan diğer bir telgraf,

${ }^{8}$ Istiklal Mahkemeleri, s. 7.

9 Nurettin Gülmez, "Bodrum, Muğla ve Çevresinde Asayiş Durumu (1918-1920)", Çağdaş Türkiye Tarihi Araştırmaları Dergisi, XVIII/Özel Sayı, 2018, s. 342.

${ }^{10}$ İhsan Sabri Balkaya, "Mütareke Dönemi Asayişin Üç Boyutu”, Atatürk Yolu Dergisi, S. 41, Mayıs 2008, s. 29.

${ }^{11}$ Atatürk'ün Tamim, Telgraf ve Beyannameleri, Atatürk Araștırma Merkezi, Ankara 1991 s. 24-25. 
yine Mustafa Kemal Paşa tarafından Havza'dan İstanbul'a gönderilmiştir. Telgrafta; Rumların, Sivas vilayetine bağlı Amasya ve Tokat sancaklarında da Samsun livasında olduğu gibi çetecilik faaliyetlerinde bulundukları ve siyasi emeller peşinde oldukları, Amasya livası dâhilinde 21 Rum çetesinin olduğu, bunların Hristiyan unsurları şımartıp asayişi bozdukları, yabancılara asayişi bozuk gösterip işgal ve müdahalelere başvurmalarını temin için hareket ettikleri, nihayet İslam ahali aleyhine eylemlerde bulundukları anlatılmıştır. ${ }^{12}$ Amasya ve havalisinde 1919 yılında Rumların yarattıkları bozguncu faaliyetler, güvenlik ve asayişi ihlal eden eylemler, bizzat bölgeye asayişi sağlamak üzere gönderilen 9. Ordu Müfettişi Mustafa Kemal Paşa tarafından yerinde tespit edilmiştir. Dolayısı ile konunun ihmal edilmesi, ertelenmesi, hafife alınması söz konusu olmamıştır. Aksine ciddiyetle üzerine gidilmesi düşünülmüştür.

Konu ile ilgili elimizdeki bilgi ve belgeler, Rumların Pontusçuluk adına yürüttükleri faaliyetlerin Amasya ve havalisinde 1920 ve 1921 yıllarında da devam ettiğini göstermektedir. ${ }^{13}$ Millî Mücadele yıllarında Anadolu topraklarının işgaline son vermek ve bağımsız yaşanılacak ortamı sağlamak amaciyla yürütülen mücadele sırasında, içte önemli bir sorun teşkil eden Pontusçu Rumların örgütlenmelerinden, tarihî emellerinden ve bölgedeki asayişi bozan eylemlerinden kısaca söz edilmesi yararlı olacaktır.

Rumların asayişi bozan, güvenliği sarsan, kargaşa yaratan ve Türk ahaliyi rahatsız eden eylemleri kendiliğinden ortaya çıkarak bölgede can ve malı tehdit eder hale gelmemiştir. Birtakım idealler, bölgedeki Rumların terör boyutundaki eylemlere katılmalarına yol açmıştır. Rumların bu idealleri "Pontus Devletini yeniden kurmak" olarak formüle edilmiştir. Bilindiği üzere XIX. yüzyılda Osmanlı Devleti'nin hakimiyeti altında yaşayan çeşitli topluluklar ve azınlıklar bă̆ımsızlıklarını elde etmek üzere harekete geçmişlerdir. Özellikle 1877-1878'deki Türk-Rus savaşında alınan yenilgi, bu dönemde Avrupa'da etkisini gösteren milliyetçilik akımı ve Avrupalı Devletlerin Osmanlı Devleti’ni parçalamaya yönelik düşünceleri, bir kısım toplulukların bağımsızlık hareketlerine girişmelerine etki yapmıştır. XX. yüzyıl başlarında bu ayrılıkçı hareketler, Anadolu topraklarında da görülmeye başlamıştır. Bu dönemde bağımsızlık hareketlerine girişen toplulukların birisi de Doğu Karadeniz bölgesinde yaşayan ayrılıkçı düşüncelere sahip Rumlardır. ${ }^{14}$ Amaçları Pontus (Pontos) adı ile tanımlanan tarihsel bölgede Pontus Rum Devleti'ni yeniden kurmaktır . ${ }^{15}$ Bu düşüncenin tarihsel kökenleri M.Ö 298 yılına

\footnotetext{
12 Tayyip Gökbilgin, Millî Mücadele Başlarken, Ankara 1959, s. 139; Mustafa Kemal Paşa'nın Havza'dan İstanbul'a gönderdiği yazıda durum ayrıntılarıyla şöyle ifade edilmiştir: " Anlaşıllyor ki Rumlar, nispetsiz derecedeki azlıklarına rağmen, Sivas Vilayetinin Amasya ve Tokat Sancaklarında da aynı Canik Livasındaki gibi çetecilik ve siyasi emeller teşkilatını tatbik ve idare ediyorlar. Bugün bilhassa Canik hududunda olmak itibari ile Amasya Livası dâhilinde 21 Rum Çetesi görünmektedir. Bunların reisleri ve faaliyet mıntıkaları bilinmektedir... Hristiyan unsurları şımartıp çılgınca vaziyetlere sokan Rum ve Ermeni kundakçıları asayişi ecnebilere karşı bozuk göstermek ve işgal ve müdahaleleri celp eylemek ve bilhassa ecnebi zabitleri olan yerlerde hükümetle hiç temas etmemek ve doğruca ecnebilere müracaat etmek gibi işleri ve Íslâmlar aleyhine vakalar meydana getirmek gibi tavir ve hareketleri devam ettiriyorlar".

${ }^{13}$ Yilmaz Kurt, Pontus Meselesi, TBMM Kültür, Sanat ve Yayın Kurulu Yayınları, Ankara 1995, s. 187-188, 262, 370-371; Arşiv Belgeleriyle Rum Faaliyetleri, s. 289, 320.

${ }_{14}$ Mustafa Balcıoğlu, "Birinci Dünya Savaşı Sırasında Karadeniz'de Rum Faaliyetleri ve Sivil Tepki”, OTAM, Sayı 4, 1993, s. 91.

15 Pontus (Pontos)'un kelime olarak deniz anlamına geldiği, sözcüğün bir milleti veya etnik bir grubu izafe etmediği, tarihsel Pontus bölgesinin kabaca Gümüşhane, Samsun ve Trabzon vilayetlerini kapsadığı ve 16. yüzyıldan itibaren Anadolu'daki Hıristiyanların nüfusça en çok bulunduğu bölge olarak tanımlanmıştır. Sait Çetinoğlu-Dara Cibran, Pontus Sorunu, Ocak 2007, s.3; bu kavramla ilgili olarak başkaca kaynaklarda da ayrıntılı bilgiler bulunmaktadır.
} 
kadar inmektedir. Nitekim İranlı bir kavim olan Persler 'in umum valisi III. Mihirdad (Mithridates I), Pont olarak tanımlanan bölgede M.Ö 302/298 de Pontus Devleti'nin kuruluşunu ilan etmiştir. ${ }^{16}$ Başkenti Amasya olan Pontus Devleti'nin hakimiyet alanı içinde Samsun, Ordu, Giresun, Trabzon Gümüşhane ve Tokat yer almıştır. Genel olarak kralları Mithridates adını taşımışlardır. ${ }^{17}$ Mithridates tarafindan kurulan Pontus Devleti'nin kurucusu ve hanedanın Yunanlı oldukları yolunda kesin tespit yoktur. Aksine kurucusu ve hanedanın Pers, tebaasının da Anadolu'nun yerli kavimleri olduğu belirtilmiştir. ${ }^{18}$ Pontus bölgesi olarak tanımlanan bu alanda yaşayan halkın büyük kısmı Ortodoks Hristiyanlardır. Bunların da Yunanlı oldukları kabul edilmemektedir. Genellikle Rumca konuşulmakta, beraberinde yerel diyalekt kullanılmakta ve kendilerine ait pek çok adetleri olduğu bilinmektedir. ${ }^{19}$ Yunanlıların bölge ile ilgilenmelerinin ve tarihi Pontus Devleti'nin mirasına sahip çıkmalarının birtakım nedenleri olmalıdır. Bu nedenlerden biri; Karadeniz kıyısında yer alan Trabzon ve Sinop'un zengin olma hevesiyle macera peşinde koşan Yunanlı gemiciler tarafından kurulduğu iddiası; diğeri ise Yunanlılık fikirleri ile beslenmiş metropolitlerin, Yunanca "Pontus" adlandırılmasından hareketle bölgeye yönelik iddialarını meşrulaştırmak istemeleridir. ${ }^{20} \mathrm{Bu}$ değerlendirmelerin dışında Yunanlıların bölge ile ilgilenmelerini açıklayan başka kayıtlar da vardır. Bu kayıtlardan birinde durum şöyle açıklanmaktadır: Pontus adı ile anılan bölgede yaşayan Ortodoks Hıristiyan nüfus, kökenleri ne olursa olsun, kilise ile yeni oluşan burjuvazinin birlikte yürüttükleri çabaların etkisi altına girerek, Yunan ulusuna ait olma duygusunu benimsemeye başlamışlardır. ${ }^{21}$

Karadeniz Bölgesi'nin bu Ortodoks Hristiyan topluluğu, Yunanlılarla bahsedildiği üzere bir bağ kurulmasının ardından Yunan emperyalizminin de etkisi ile Bizans İmparatorluğu'nu canlandırma hayaline kapılmışlardır. Ekonomik güç olarak Türklere nispetle daha iyi konumda olan Rumlar, kendilerini adeta Bizans İmparatorluğu'nun birer savaşçısı olarak görmeye

Bunlardan biri Yusuf Gedikli tarafından yayına hazırlanan "Pontus Meselesi” adlı eserdir. Eserde, M.Ö 520 de Persler zamanında Pontus Satraplığı (Eyalet) olarak adlandırılan bir bölgeden söz edilmektedir. Pontus satraplığının merkezi Amasya'dır. Sınırları geniş bir alana yayılmış olup, Samsun, Ordu, Giresun, Trabzon, Gümüşhane, Erzurum, Muş, Erzincan, Sivas, Tokat ve Çorum'u kısaca, Kızılırmak yayının içinde kalan yerleri kapsamıştır. Ancak, Pontus coğrafyasının sınırları pek çok kere değişmiş sonraları, Sinop, Kastamonu, Zonguldak ve hatta İstanbul'a kadar uzanan sahil bölgesi ile Batum'un kuzeyi ve sahil Gürcistan'ını içine almıştır. (Yayına Hazırlayan: Yusuf Gedikli, Pontus Meselesi, İz Yayıncılık, İstanbul 2008, s. 16-17; Ayrıca Yılmaz Kurt, age, s. 60; Mehmet Özsait, Anadolu'da Helenistik Dönem, Anadolu Uygarlıkları Ansiklopedisi II, İstanbul 1982, s. 296; Ayrıca Amasya Tarihi yazarı Abdizâde Hüseyin Hüsameddin Efendi'nin, Pont Hükümet merkezinin Amasya olduğunu, Amasya çevresi için Pont Amasya tanımlamasını yaptığını görmekteyiz, Amasya Tarihi (Yayına Hazırlayanlar: Mesut Aydın-Güler Aydın), Cilt 1, Amasya 2007,s.8-12.

${ }^{16}$ Mehmet Okur, "Pontus Meselesinin Ortaya Çıkışı ve Karadeniz Bölgesinde Pontusçu Faaliyetler", Karadeniz Araştırmaları Dergisi, Sayı 14,(Yaz 2007), s. 3.

17 Salih Kaymakçı, “Amasya-Oluz Höyük' te Mithradates VI Eupator Dönemi”, Uluslararası Amasya Sempozyumu (4-7 Ekim 2017), Bildiriler Kitab1, Cilt 1, Amasya 2017, s. 286

${ }^{18}$ Gedikli, age, s. 17; Devletin kuruluşu bu eserde M.Ö 298 olarak belirtilmiş, Hamit Pehlivanlı'nın “Tarih Perspektifi İçerisinde Pontus Olayı” adlı makalesinde Tarihi Pontus Krallığının kuruluşu M.Ö 301 olarak gösterilmiştir. Yıılmaz Kurt'un yayına hazırladığı "Pontus Meselesi" adlı eserde kuruluşla ilgili net bir tarih yoktur. Yıkılış ile ilgili bilgi verilmiştir. Buna göre; Mihirdad tarafından kurulan Pontus Hükümeti M.S 65. yılma kadar devam etmiş, sonra Roma eyaleti olmuş ve Sezar zamanında Pont bölgesi Roma'ya bağlanarak iki vilayete taksim olunmuştur. Ayrıca, bakınız; Mahmut Goloğlu, Anadolu’nun Milli Devleti Pontus, Ankara 1973, s. 53,72.

${ }^{19}$ Sait Çetinoğlu-Dara Cibran, Pontus Sorunu, Ocak 2007, s. 3.

${ }^{20}$ Serpil Sürmeli, "Samsun ve Çevresinde Pontus Hareketi”, Atatürk Yolu Dergisi, Sayı 19, 1997, s. 326.

${ }^{21}$ Stefanos Yerasimos, Pontus Meselesi (1912-1913), Toplum ve Bilim, 43-44, Güz-Kış 1989, s. 34. 
başlamışlardır. ${ }^{22}$ Böylelikle "Pontus Meselesi" denilen konu gündeme getirilmiştir. Bu mesele, 19. Yüzyıl sonlarında özellikle İngiltere, Fransa, Rusya ve Amerika tarafindan desteklenen ve Yunan Megalo İdeasının bir uzantısı olarak Karadeniz Bölgesi'nde kurulması planlanan bir devletin doğuşunu hazırlamak üzere ortaya konmuştur. ${ }^{23}$ Tanzimat döneminde, Islahat Fermanı ile gayri Müslimlere yeni hakların ve ayrıcalıkların verilmesi bu sürece katkı sunmuştur. ${ }^{24}$ Nitekim 1904 yılında Rumlar, Yunanistan ve Amerika'nın yardımıyla amaçlarını gerçekleştirmek üzere İnebolu'da ilk Pontus teşkilatını kurmuşlardır. Aynı tarihlerde Merzifon Amerikan Koleji bünyesinde iki tane gizli Pontusçu cemiyet kurulmuştur. Bu cemiyetlerden biri "Rum İrfan Perver Cemiyeti" diğeri "Orpheus" adlı musiki cemiyetidir. Bu cemiyetler, 1904 yılında birleşerek "Pontus Cemiyeti" adını almıştır. Cemiyet "Pontus" adlı bir gazete çıkararak, Rum halkını harekete geçirmek istemiştir. ${ }^{25}$

İkinci Meşrutiyet'in ilanından sonra Pontusçu harekât, sözde davalarını kazanmak ve başarı elde etmek için güç kullanmaya yönelmiştir. Anadolu'da misyonerlik faaliyetlerinde bulunan Amerika'nın teşvik ve himayesini gören Rumlar, bu dönemde örgütlenme faaliyetlerini artırarak Trabzon'da Pontus Muavenet Cemiyeti, Amasya'da Mukaddes Anadolu Rum Cemiyeti, Samsun'da Muhacirin Cemiyeti yine Samsun'da Teceddüt ve İhya Cemiyeti ile İnebolu, Fatsa, Kayseri, Kırşehir, Sinop, Bafra, Havza, Tokat ve Çarşamba'da şubeleri bulunan Müdafaa-i Meşruta Cemiyetlerini kurmuşlardır. ${ }^{26} \mathrm{Bu}$ doğrultudaki çalışmalar, Rumların hayli mesafe almalarını sağlamıştır. Nihayet Birinci Dünya Savaşı ve takip eden mütareke yıllarında söz konusu destek ve himayelerden güç alan Rum çeteleri, ülkedeki otorite boşluğundan, siyasi ve askeri ortamın karmaşıklığından faydalanarak eylemelere girişmişlerdir. Türk-Müslüman nüfusun yoğunlukta olduğu Karadeniz Bölgesi'nde etnik temizlik ve nüfus azaltma uygulamalarına girişmişlerdir. Bu tür hareketler, İstanbul'daki Rum Patrikliği ve Karadeniz Bölgesi'ndeki Rum-Ortodoks din adamları tarafından da desteklenmiştir. Bunların yanında özellikle Rum Papazların, Trabzon metropoliti Hrisantos ile Amasya metropoliti Karavangelis'in destek ve kışkırtmaları bölge Rumlarının Pontus Cumhuriyeti’ni kurma heyecanını artırmış, ciddi saldırılarda bulunmalarına yol açmıştır. ${ }^{27}$ Genellikle eylemler askerden kaçma, eşkıyalık yapma, seferberlik emrine uymama başta olmak üzere Müslüman nüfusu azaltmak için Müslüman ahaliyi katletme, köylerini yok etme, yakma ve yağmalama şeklinde vuku bulmuştur. Bu tür eylemlerin bir başka amacı da Osmanlı Devleti döneminde Osmanlıyı, TBMM Hükümeti döneminde de yeni

\footnotetext{
${ }^{22}$ Abdullah Saydam, “Kurtuluș Savaşında Trabzon’a Yönelik Ermeni-Rum Tehdidi”, Atatürk Araștırma Merkezi Dergisi, Cilt 6, Say1 17, Mart 1990, s. 422.

${ }^{23}$ Hamit Pehlivanl,, "Tarih Perspektifi İçerisinde Pontus Olayı: Yakın Tarihimize ve Günümüze Etkileri”, Atatürk Araştırma Merkezi Dergisi, Cilt X, Sayı 29, Temmuz 1994, s. 358.

${ }^{24}$ Enver Ziya Karal, Osmanlı Tarihi, Türk Tarih Kurumu Basımevi, Ankara 1983, Cilt IV, s. 1-6.

${ }^{25}$ Nuri Yazıc1, Millî Mücadelede Pontusçu Faaliyetler, 1918-1922, Ankara 1989, s. 39-45; Gedikli, a.ge, s.101-105.

${ }^{26}$ Balcıŏlu, agm, s. 92.

${ }^{27}$ M. Murat Hatipoğlu, "Gerçek ve Sanal Ortamlarda "Pontus Meselesi: Uluslararası İlişkilerde Asılsız İddialara ve Bilgi Kirliliğine Somut Bir Örnek”, Uluslararası Asya ver Kuzey Afrika Çalışmaları Kongresi, 38. ICANAS, Bildiriler, 10-15.09.2007, Cilt I, Ankara 2011, s. 834; Bu çalışmada Amasya metropolitinin Gennadiyos Karavenğelis olduğu ifade edilmiştir. Pontus Meselesi hakkında bilgi veren çalışmalarda genellikle Amasya'da bir metropolitliğin varlığından söz edilmekle beraber metropolitin ismi pek zikredilmemektedir. Bazı çalışmalarda Amasya metropoliti olarak Samsun'da görev yapan Yermanos (Germanos) Karavengelis'den söz edilmektedir. Bu kişilerin ikinci adlarında benzerlik bulunmaktadır. Bunların aynı kişiler olup olmadıkları tespit edilememiştir.
} 
Türkiye'yi zayıf düşürmek, üzerlerine kuvvet çekerek işgalcilere karşı yürütülen mücadeleyi zora sokmak, orduyu arkadan vurmak ve nihayet bölgedeki Rumların çoğunlukta olduğunu ispatlayarak Türklerin yenilmesi durumunda tarihi emellerini gerçekleştirmek olmuştur. ${ }^{28}$

Görüldüğü üzere Anadolu toprakları, hem Osmanlının son döneminde Birinci Dünya Savaş1 ve mütareke devresinde hem de TBMM açılıp Millî Mücadelenin yürütüldüğü sırada güvenlik ve asayişi bozarak terör eylemelerini sürdüren Pontusçu Rumların tehdit ve tehlikeleri ile karşı karşıya kalmıştır. Kısaca bilgi verdiğimiz Pontusçu Rumların çetecilik ve bozguncu faaliyetlerine karşı hükümet idari ve askeri tedbirler almak zorunda kalmışıtır. Alınan tedbirler ve başvurulan uygulamalar, çalışma konumuz olan Amasya ve havalisi için de geçerli olmuştur. Eylemler ağırlıklı olarak tüm Karadeniz bölgesinde yaşanmış olmakla beraber biz burada çalışmamızın öznesi olan Amasya vilayetindeki Pontusçuluk olarak adlandırılan bozgunculuk ve terör faaliyetleri ile bunlara karşı alınan önlemler üzerinde duracağız.

\section{2- Amasya Mıntıkasında Pontusçu Hareketler}

Coğrafi konum itibarı ile Orta Karadeniz Bölgesi’nde yer alan Amasya'nın, milattan önceki yıllardan süregelen önemli bir merkez olduğu yukarıda belirtilmişti. Amasya'nın tarihsel önemi Osmanlı Devleti'nin son zamanlarında, Birinci Dünya Savaşı ve sonrasında başlatılan Millî Mücadele döneminde de devam etmiştir. Konumuzla ilgili olarak bakıldığında, bölgenin Pont, Pontus, Pontus Cumhuriyeti veya Pontus Krallığ şeklindeki isimlendirmeler, Karadeniz Bölgesi'nde birçok şehir ve kazayı içine alan geniş bir bölge için kullanılmışsa da bunun yanında Amasya merkezli bir mıntıkayı tanımlamak üzere de kullanıldığı görülür. Tarihi belge ve bilgiler bunu doğrulamaktadır. ${ }^{29}$ Amasya'nın Tarihi Pontus Krallığı'nın merkezi olarak bilinmesi veya kabul görmesi durumu, bu vilayete tüm zamanlarda muhataplarının ilgisini artırmıştır. Bunun sonucu olarak 19. yüzyıl sonlarından itibaren Pontus Devleti'ni yeniden kurmaya yönelik adımlar ve faaliyetler yoğunluk kazanmıştır. Bu devletin yeniden inşasını bir dava gibi gören yerli Rumlar dışardan aldıkları destek ve yardımlarla, içerde Ortodoks din adamları ve metropolit olarak görevlendirilenlerin kışkırtmaları ile Karadeniz Bölgesi'nin diğer vilayet ve kazalarında olduğu gibi Amasya havalisinde de asayiş ve düzeni bozucu eylemlere girişmişlerdir.

Amasya ve havalisindeki Pontusçu faaliyetler, 20. yüzyıl başlarında da devam etmiştir. Bu konuda bilgi veren kaynaklar, ilk Pontusçu örgütlenmelerin Amasya'nın Merzifon kazasında başladığını göstermektedir. Eldeki belgelere göre Pontus Örgütünün ilk kurulduğu yer Merzifon'dur. Burada bulunan Amerikan Koleji'nde yapılan aramada, 1904 tarihli Pontus Cemiyeti tüzüğü ele geçirilmiştir. ${ }^{30}$ Tüzükten başka, resmi mühür, bayrak, arma, silahlar, eski

\footnotetext{
${ }^{28}$ Sabahattin Özel, Millî Mücadele'de Trabzon, Ankara 1991, s. 33; Saydam, agm, s.425.

29 Pontus Krallığının kurulus yeri ile ilgili ilk bilgiler Amasya'yı göstermektedir. Amasya ve civarı M.Ö 300/298'den itibaren Krallığın hâkimiyet alanı olarak gösterilmiştir. Sonraki yıllarda Krallığın merkezi değişmiştir. Hüseyin Hüsameddin, age, s. 8; Yusuf Gedikli, age, s. 17-101; Y1lmaz Kurt, age, s. 152.

30 Merzifon Amerikan Koleji, 1863 yılında Amerika Birleşik Devletleri ile Osmanlı Devleti arasında yapılan görüşmeler sonunda Ruhban Okulu olarak açılmıştır. Başlangıçta Amerikan Board komisyonu üyelerinden Marsovan tarafından kurulan okula, daha sonra Anadolu Koleji adı verilmiş, ilerleyen yıllarda Ruhban Okulundan ayrı bir kurum olarak değerlendirilmiştir. Okul 1921 yılında Türkiye Cumhuriyeti sınırları dışına çıkarılmıştır; Gülbadi Alan, Merzifon Amerikan Koleji ve Anadolu'daki Etkileri, Doktora Tezi, Erciyes Üniversitesi Sosyal Bilimler Enstitüsü 2002, s. 195-201. (Tez 2018 y1lında Türk Tarih Kurumu tarafindan Amerikan Board'ın Merzifon'daki Faaliyetleri ve
} 
Pontus madalyaları, kasa, defter, Pontus Dergisi, Pontusçu çetelerin fotoğrafları, müzik notaları ve marşlardan oluşan dokumanlar bulunmuştur. ${ }^{31}$ Amerikan Board misyonerlerinin kontrolü altında tutulan okulun temel politikası, takip edilen ders programları ve okutulan kitaplarla öğrencilere hürriyet fikirlerini aşılamak ve milli şuuru uyandırmaktır. Diğer bir ifade ile okul, azınlık gençlerini fikren ve zihnen Osmanlı Devleti aleyhine yönlendirmeye, devlete isyan etmeye ve Pontusçuluk hayallerini özellikle Rum öğrencilerin kafasına yerleştiremeye odaklanmıştır. ${ }^{32}$ Kolejin bu yönlü çalışmaları, bölgedeki potansiyel Pontusçu faaliyetlere temel oluşturmuştur. Nitekim sonraki yıllarda Samsun Sancağı dâhil olmak üzere Amasya ve havalisinde Rum eşkıyaların Türk köylerini basarak halkı katlettiklerine ilişkin olaylar, mecliste dile getirilmiştir. ${ }^{33}$ Bölgedeki durum, bizzat Mustafa Kemal Paşa'nın 24.4.1336/1920 tarihinde mecliste yaptığı konuşmasında da vurgulanmıştır. O konuşmasında:

“... Atina tarafindan idare olunan Pontus Hükümetinin emelinin, Karadeniz sahiliyle kısmen Amasya ve Tokat'ın kuzey kazalarında yerleşik bulunan Rumların hayal hanelerini çılgınca bürüdüğ̈̈ne..."

işaret etmiştir. ${ }^{34}$ Benzer şekilde Meclis'in 18.5.1338/1922 tarihli oturumunda Amasya ve Tokat mıntıkasında, Rum eşkıyaların 5-6 seneden beri yaptıkları mezalimler gündeme getirilmiştir. Bu kapsamda eşkıyaların rastladıkları köylerde kadınları katlettikleri, mallarına zarar verdikleri, geride kalan yaşlıların ve sağ kalan kadınların ise ellerinde kalan 5-10 adet hayvanının emniyetini temin edemediklerine ilişkin haberlerin geldiği belirtilerek, Rumların bölgedeki bozguncu hareketlerine dikkat çekilmiştir. ${ }^{35}$ Söz konusu öldürme ve katletme olaylarının kazıklamak, ağaca bacağından asmak, yakmak ve türlü işkenceler yapmak şeklinde olduğu; öldürülenlerin cesetlerinin toprak üzerinde çürümeye bırakıldığ 1 , bir kısmının ırmağa atıldığı yolundaki bilgiler meclisin gizli oturumunda dile getirilmiştir. ${ }^{36}$

Amasya ve civarında Pontusçu Rumların eylemleri, gerek Merzifon'daki Amerikan Koleji ile ilgili tutulan raporlardan gerekse Amasya Sancağı, Merzifon, Gümüşhacıköy, Gümüş Madeni nahiyesi ile Havza, Lâdik ve Erbaa'da yaşanan öldürme, yaralama, yakma, taciz, ırza geçme, gasp ve göçe zorlama gibi vakaların yer aldığı cetvellerden öğrenilmektedir. Ayrıca Merkez Ordusu komutanı olarak atanan Nurettin Paşa'nın Müdafaa-1 Milliye Vekâletine gönderdiği

\footnotetext{
Anadolu Koleji başlı̆̆ı ile kitap olarak yayınlanmıştır); Ayrıca, İlknur Polat Haydaroğlu, Osmanlı İmparatorluğu'nda Yabancı Okullar, Kültür Bakanlığı Yayınları, İstanbul 1990, s.136.

${ }^{31}$ Yilmaz Kurt, age, s. 152.

32 Gülbadi Alan, “Amerikan Board Okullarında Yürütülen Misyonerlik Faaliyetleri”, Journal of Islamic Research, 20(4), 2007, s. 472.

33 TBMMZC (Türkiye Büyük Millet Meclisi Zabıt Ceridesi), C. 13, Devre 1, 98. içtima, s. 229; TBMM'nin 22.10.1337/1921 günü yapılan toplantısında, Lâzistan Mebusu Osman Bey’in 15.10.1337/1921 tarihinde Rumların bozguncu hareketlerine ilişkin Meclis Başkanlığına verdiği yazılı başvurusu görüşmek üzere gündeme alınmıştır. Osman Bey, başvurusunda: Samsun ve Amasya livalarında eşkıyalık yapan Rumların olduğunu, eşkıyalık eylemelerinin çoğaldığını, bu kadar çoğalmasına kimlerin sebebiyet verdiğini, bunların derdest edilmesi ve önlenmesi için ne gibi tedbirler alındığını sormuş ve bu konuda Dâhiliye Vekâletinden açıklama yapılmasını istemiştir. Osman Bey'in konuyu meclis gündemine taşıması ve mecliste konunun tartışılması bölgede asayiş ve güvenliğin endişe verici boyutta olduğunu göstermektedir.

${ }^{34}$ TBMMZC, C. 1, Devre 1, 2. İçtima, s. 9.

35 TBMMZC, C. 20, Devre 1, 44. İçtima, s. 68.

${ }^{36}$ TBMMGCZ (Türkiye Büyük Millet Meclisi Gizli Celse Zabıtları, C. 3, 51. Birleşim, Celse. 3, Türkiye İş Bankası Kültür Yayınları, Ankara 1985, s. 386.
} 
şifreli raporlardan, diğer bilgi ve belgelerden yörede 1919-1922 yıllarında ciddi sorunlar yaşandığı anlaşılmaktadır. ${ }^{37}$ Örnek oluşturması nedeniyle 1919 yılı Ağustos'undan 1920 yılı Ağustos ayına kadar bir yıllık sürede sadece Amasya kazası ve yakın civarda yaşanan bozguncu eylemlerden söz etmekte yarar vardır. Bu devrede sayıları oldukça kalabalık Rum çeteleri tarafindan 23 adet suç işlendiği tespit edilmiştir. Bunlar içinde en dikkate değer eylemlerden biri, Amasya'nın Karaağaç karyesi ile Zigere (Muhtemelen bugünkü Ziyere denilen Ziyaret kasabası) mahallesine, civardaki Rumlardan oluşan 100 kişilik bir çetenin baskın yapmasıdır. Eşkıyalar, önceden tespit ettikleri mahallenin zenginlerinden 43 haneyi soyup yağma etmişler, para, eşya ve hayvan namına ellerine ne geçtiyse gasp etmişler, 2 kişiyi katledip, 1 kişiyi de yaralamışlardır. Nihayet mahallenin tüm kadınlarını bağırtarak sopalarla dövmüşlerdir. Yine aynı tarihlerde devriye görevi nedeniyle köylerinden geçen atlı Türk askerlerine ateş açılmıştır. Rum eşkıyası, şehit olan askerlerin cesetlerini tarlaya gömmüş, sonra üzerlerine de misır ekmişlerdir. Bu suça bulaşmış olanlar tutuklanmışlarsa da kısa süre sonra firar etmişlerdir. Kayıtlarda 17 köye saldırıldığından, köylülere ait eşya ve hayvanlar ile 500 liralık ticarî malın çalındığından ve insanlara kötü muamele yapıldığından söz edilmektedir. ${ }^{38} \mathrm{Bu}$ doğrultuda benzer olayların yaşandığı birçok örnek gösterilebilir.

Amasya ve çevresindeki kaza ve nahiyelerde, Rumların eşkıyalık faaliyetlerine ilişkin olarak hazırlanan cetvellerde her bir olayın kim, nerede ve hangi çete tarafından gerçekleştirildiği, ne tür bir eylem yapıldığı, kimlerin öldürüldüğg̈ veya gördüğü zarar ayrıntılı bir şekilde yer almıştır. Çoğu olay yöre kaymakamı, komiser, jandarma kumandanı, mıntıka komutanı, nahiye müdürü, muhtar, aza ve köy imamı gibi kimselerin beyanları ile tutanak altına alınmıştır. Bölgedeki asayişi, güvenliği ve düzeni bozan eylem ve olaylara ilişkin listeler, vesikalar ve fotoğraflar raporlar halinde yetkililere iletilmiştir. Meclisteki tartışmalar ve müzakereler, bu yönde iletilen bilgiler üzerine yapılmıştır. Müzakerelerin ciddiyetle sürdürülmesi, tartışılması, hal çaresi aranması, bu konuda hazırlanan raporlar ve vukuat cetvellerindeki yer alan veriler o günlerin zorluğunu göstermektedir. Bu durum karşısında hükümet etkili önlemler almak zorunda kalmıştır. Aşağıda alınan önlemler ve yapılan düzenlemeler hakkında bilgi verilecektir.

\section{2- Güvenlik ve Asayiş Sorununa Karşı Alınan Önlemler ve Yapılan Düzenlemeler}

Mütareke dönemi ve ardından başlayan Millî Mücadele döneminde sözde Pontus Rum Devleti'ni kurma amacıyla hareket eden ve batılı devletlerin de desteğini alan Rum çetelerinin eylemleri, gittikçe şiddetini artırmış ve bazı mıntıkalarda kontrol altına alınamaz olmuştur. Bu durumu Mustafa Kemal Paşa Nutuk’ta:

“... Pontus eşkıyasının kuvveti başlangıçta 6.000-7.000 silahlı idi. Daha sonra her taraftan katılanlarla 25.000'e yaklaştı. Bu kuvvet yeterli küçük birliklere ayrlarak, çeşitli yerde barınıyordu. Pontus çetelerinin bütün işleri İslam köylerini yakmak, Müslüman halka karşı akll ve hayale slğmaz zulümler yapmak, cinayetler işlemek gibi kan içici sürünün yaptıklarından başka bir şey değildi”,.

\footnotetext{
${ }^{37}$ Gedikli, age, s. 315-392; Arşiv Belgeleriyle Rum Faaliyetleri, s. 289, 320.

${ }^{38}$ Kurt, age, s. 262; Pontusçu eşkıyaların yapmış oldukları eylemler tarih, yer ve işlenen suçlar liste halinde verilmiştir, s. 263-340; Gedikli, age, s. 316.
} 
sözleri ile özetlemiştir. ${ }^{39}$ Konuşmasının devamında, kısa zamanda hızlı bir şekilde alınan tedbirleri de şöyle ifade etmiştir:

\begin{abstract}
"Biz Anadolu'ya çıkar çıkmaz Türk halkını dikkat ve uyanıklı̆ga davet ettik. Doğabilecek tehlikelere karşı tedbirler almaya başladık. Merkezi Sivas'ta bulunan 3. Kolordu, yalnız çeşitli bölgelerde gözüken çeteleri takip ve ortadan kaldırmakla uğraştı. Trabzon bölgesinde dolaşan Köroğlu adındaki Rum çetesiyle, Eftali çetesi ve öteki çeteler, merkezi Erzurum'da bulunan 15. Kolordu tarafindan takip edilerek ortadan kaldirllyyorlardl. Bir taraftan da Pontus eşklyasının dönüp dolaştığı yerlerde, halk silahlandırllarak millî teşkilat kuruldu". ${ }^{40}$
\end{abstract}

Gerçekten de söylendiği gibi konu ciddiyetle ele alınmıştır. Diğer taraftan Samsun ve Amasya mıntıkasında cereyan eden olayların bastırılması için bir kısım jandarma birlikleri ile 15. Tümen ve 5. Kafkas Tümenine bağlı alaylardan bazıları bölgeye gönderilmiştir. Ancak 1919 yılında baş gösteren bu Pontusçu eylemlere karşı verilen mücadeleden istenen başarı elde edilememiştir. Aynı tarihlerde batıda Yunan ilerleyişi ve Anadolu'da çıkan iç isyanlar nedeniyle bu eylemlere karş1 verilecek mücadele güçleşmiştir. Yaşanan tüm bu olumsuzluklar üzerine hükümet tarafından etkili tedbirler alınıp bir düzen kurulmaya çalışılmıştır. Bu yönlü çalışmalardan biri; Pontusçu faaliyetleri engellemek ve Anadolu'nun orta kesiminde var olan asayiş sorununu çözmek için bölgedeki kuvvetlerin bir komuta altında toplama kararının alınmasıdır. ${ }^{41}$ Ankara hükümetinin aldığg bu karar uyarınca karargâhı Amasya'da olacak Merkez Ordusu kurulmuştur. Alınan tedbirlerden diğerleri ise; bölgede sıkıyönetim ilanı, İstiklal Mahkemesinin kurulması, Rumların göç ettirilmesi, silahların toplanması, bir kısım teşkilatların kurulması ve çalışmamızın konusu olan Amasya ve Havalisi Kuva-yı Takibiye Kumandanlığını kurma çalışmalarıdır. Alınan bu tedbirlerin her biri hakkında aşağıda bilgi verilmiştir.

\title{
2.1- Merkez Ordusunun Kurulması
}

Millî Mücadele döneminde birçok sorunun yanında içerde güvenliğin tesis edilmesi, asayişin sağlanması ve normal bir düzenin kurulması çözümlenmesi gereken bir konu olarak belirmiştir. Cephede mücadele verilirken ne yazık ki cephe gerisinde güvenlik problemleri ile karşı karşıya kalınmıştır. İçinde bulunulan bu duruma çareler bulmak üzere TBMM'de 24 Nisan 1920 ile 13 Nisan 1922 tarihleri arasında yaklaşık 27 gizli oturum yapılmış, konu uzunca tartışılmıştır. Bu tartışmalarda, güvenlik ve asayişin bozulma sebebi olarak Karadeniz Bölgesi'nde Pontusçu faaliyetler ile Anadolu'nun çeşitli bölgelerinde baş gösteren ayaklanma ve eşkıyalık hareketleri gösterilmiştir. Bunun yanında güvenliğin sağlanmasında bir kısım içsel eksikliklerin olduğu da görülmüştür. Eksiklikler; kanun hâkimiyetinin sağlanmasındaki eksiklik, idarede görevli memurların yetersizliği, otorite boşluğunun olması ve olağanüstü uygulamaların yarattığı sıkıntılar şeklinde sıralanabilir. ${ }^{42}$ Bölgede, bu dönemde tüm olumsuzluklar yanında asayişin ve güvenliğin bozulmasında Pontusçu Rumların faaliyetlerinin etkili olduğu kabul edilmiştir. Bu nedenle Amasya ve havalisinde Rumların bozguncu hareketlerinin önüne geçmek üzere hükümet

${ }^{39}$ Nutuk, s. 426.

${ }^{40}$ Age, s. 426.

${ }^{41}$ Zeki Çevik-Filiz Özkan, "Pontus Terörünün I. Meclise Yansımaları (1920-1923)”, Editör Osman Köse; Osmanlıdan Günümüze Eșkıyalık ve Terör, Samsun İlk Adım Belediyesi Kültür Yayınları, Samsun 2017, s.657-658

${ }^{42}$ Mehmet Evsile, "Millî Mücadele Sırasında Cephe Gerisinde Güvenlik Problemleri”, Editör Osman Köse; Osmanlıdan Günümüze Eşkıyalık ve Terör, Samsun İlk Adım Belediyesi Kültür Yayınları, Samsun 2017, s.491-504. 
tedbir almak gereğini duymuştur. Yukarıda bahsedildiği üzere bölgedeki kuvvetleri birleştirmek ve etkin mücadele etmek için 9 Aralı 1920 tarihinde, karargâh merkezi Amasya olan yeni bir ordu kurulmuştur. Merkez Ordusu olarak adlandırılan bu yeni ordunun kuruluşu ile Sivas'ta bulunan 3. Kolordu lağvedilmiştir. Merkez Ordusu, 5'nci, 15'nci ve kurulmakta olan 6'nc1 Atlı Piyade Tümenlerinden oluşturulmuş, komutanlığına da Nurettin Paşa getirilmiştir. Merkez Ordusunun yetki alanı Sivas, Samsun, Sinop, Tokat, Çorum, Amasya ve Yozgat olarak belirlenmiştir. ${ }^{43}$

Merkez Ordusu yaklaşık on bin kişilik bir kuvvete sahip olarak, 1921 yılında göreve başlamıştır. Aldığı tedbirlerden ilki, Pontusçuların ellerindeki silahların toplatılması olmuştur. Bu konuda TBMM'den izin alınması düşünülmüştür. TBMM, Pontusçularla ilgili tedbirler alırken Rumların hayatlarına dokunulmayacağı, silahlarını teslim etme şartıyla suçlarının affedileceği gibi hususları mutasarnflı̆̆a bildirmiştir. Silahların teslimi için bir haftalık süre verilmiş, buna uyulmaması halinde başka tedbirlere başvurulacağı hatırlatılmıştır. ${ }^{44}$ Silahların toplanması yönünde Merkez Ordusuna ve mülki idareye talimat verilmiş ise de Hristiyan ahali silahlarını teslim etmeyerek Bafra taraflarında Nebyan/Nebiyan bölgesine çekilmişler, burasını merkez yaparak civardaki Müslüman köylerine saldırılarda bulunmuşlardır. Aynı günlerde Batı Cephesinde Yunan saldırılarının ve Çerkez Ethem'in yarattı̆g 1 rahatsızlıktan dolayı Ankara Hükümeti geçici olarak silahların toplatılmasından vazgeçmiştir. ${ }^{45}$

İkinci tedbir: Pontus davasına hizmet edebilecek gayri Müslim kimseleri Türkler gibi silah altına almak olmuştur. Askere alınma ile ilgili çağrıya uymayanların birçoğu evlerini terk edip, silahlanarak dağlara çekilmişlerdir. Merkez Ordusu dağlara çekilenlere, dönmeleri halinde affedileceklerini duyurmuşsa da bu çağrıya kimse uymamıştır.

Merkez Ordusunun Amasya ve civarındaki aldığı üçüncü tedbir; Merzifon Amerikan Kolejine yönelik tedbirdir. Kolejde yapılan arama sırasında ele geçirilen dokumanlar ve Pontus Örgütü ile bağlantılarını belgeleyen yazışma metinleri, okulun Rumları, Yunan emellerinin gerçekleşmesi ve Pontus Hükümetinin kurulması için kışkırttığını ortaya koymuş; dolayısı ile zararlı faaliyetlerde bulunduğunun tespiti yapılmıştır. Merkez Ordusu Komutanı Nurettin Paşa, konuyla ilgili olarak 16 Şubat 1921 tarihinde Amasya'dan Erkan-1 Harbiye Umumi Riyaseti'ne bir rapor göndermiştir. Raporda, kolejde aramalarda ele geçirilenler ile okulun Ermeni ve Rum gençlerine yönelik eğitim faaliyetlerinden bahsedilmiştir. ${ }^{46}$ Bir gün sonra, yani 17 Şubat1921 tarihinde bu kez Müdafaa-1 Milliye Vekâletine şifreli bir rapor göndermiştir. Bunda ise bir gün önceki kolejde yapılan aramalarda ele geçirilen belgelerden, bunların tercüme edildiğinden, tutuklu Ermenilerin olduğundan ve sorgulamaların devam ettiğinden bahsedilmiştir. ${ }^{47} 26$ Şubat 1921 tarihli Erkan-1 Harbiye Umumi Riyaseti'ne gönderilen diğer raporda ise Amasya'da bir Divan-1 Harb-i Örfi'nin

\footnotetext{
${ }^{43}$ Mustafa Balcıoğlu, "Millî Mücadele Sırasında Merkezi Anadolu'da Asayişi Sağlamak İçin Oluşturulan Milis Kuruluşları", Atatürk Yolu Dergisi, Say1 6, 1990 s. 261; Pelin İskender Kılıç (2011), "Samsun ve Çevresinde Pontus Çetelerinin Faaliyetleri ve Hükümetin Uygulamaları”, Turkish Studies, Volume 6/2, s. 498.

${ }^{44}$ Ulvi Keser, "Milli Mücadele Döneminde Ayrılıkçı Faaliyetlerde Kilisenin Rolü ve Hrisostomos-Hrisantos Girişimlerine Kesitsel Bir Bakış”, ”, Editör Osman Köse; Osmanlıdan Günümüze Eşkıyalık ve Terör, Samsun İlk Adım Belediyesi Kültür Yayınları, Samsun 2017, s. 610.

${ }^{45}$ Çevik- Özkan, agm, s. 658; Pehlivanlı, agm, s.369.

${ }^{46}$ Arşiv Belgeleriyle Rum Faaliyetleri, s. 284.

${ }^{47}$ Age, s. 289.
} 
(Sıkıyönetim Mahkemesi) kurulması için emir buyurulması, arz ve teklif edilmiştir. ${ }^{48}$ Merkez Ordusunun kolej ile ilgili çalışmaları sonucunda, kolejdeki Amerikalılar sınır dışı edilmiş, bir kısım Pontusçu tutuklanarak yargılanmak üzere Amasya'ya gönderilmiştir. Amasya İstiklal Mahkemesinde kolejin kulüp üyelerinden altısı yargılanmış; sanıkların Yunan emelleri doğrultusunda eğitim yaptırdıkları, otoriteye karşı gelmek için üye kaydettikleri ve okulun Türkçe öğretmeni Zeki Bey'in ölümüyle ilgili görülmeleri nedeniyle haklarında idam kararı verilmiştir. ${ }^{49}$ Dâhiliye Vekâleti okulda yaşanan benzer birçok olayı gerekçe göstererek, Amasya Mutasarrıflığına okulun kapatılması ile ilgili bir tebliğ göndermiş, Mutasarrıflık, bakanlığın tebliği uyarınca okulu kapatmıştır. Bina kapısı, kaymakamlıkça mühürlenmiş, yapılan işlemler 24.3.1921 tarihinde Dâhiliye Vekâletine bildirilmiştir. ${ }^{50}$ Merkez Ordusunun kurulmasından itibaren Amasya mıntıkasındaki Pontusçu Rumların takibine ve alınan önlemlere yönelik bilgiler, Nurettin Paşa tarafından Müdafaa-1 Milliye Vekâletine günü gününe rapor edilmiştir. ${ }^{51}$

Alınan tedbirlerden bir diğeri Yunan donanmasının İnebolu'yu bombalaması ve ardından Samsun'a çıkarma yapması ihtimaline karşı, 15 yaşından 50 yaşına kadar olan Rumların iç bölgelere sevk edilmesine dair 16 Haziran 1921 tarihli Bakanlar Kurulu Kararının çıkarılmasıdır. ${ }^{52}$ Bu kapsamda Amasya havalisi dâhil Samsun, Ordu ve Giresun'da eli silah tutan Rum erkekleri iç kısımlara sevk edilmiş, 1901 doğumlular da askere alınıp amele taburlarına gönderilmiştir. Rumların aileleri ile birlikle göç etmek istemeleri halinde müracaat edenlere izin verileceği, yolculukları sırasında her türlü can, mal ve irz güvenliklerinin devletin teminatı altında olacağı, buna uymayanların cezalandırılacağı bildirilmiştir. Alınan tüm tedbirlere rağmen Rumların iç kesimlere sevki arzu edildiği gibi yapılamamıştır. Aileleri ile sevk edilen Rumların her ne kadar can ve mallarının korunmasına özen gösterildi ise de bazı olumsuzluklar

\footnotetext{
${ }^{48}$ Age, s. 320.

${ }^{49}$ Pehlivanli, agm, s. 370.

${ }^{50}$ Kurt, age, s. 376; Okulun kapatılması serüveni Nazan Maksudyan'ın “Amerikan Kaynaklarında Merzifon Anadolu Koleji'nin Kısa Tarihçesi” adlı makalesinde şöyle özetlenmiştir: “...Kolej’de Türkçe öğretmeni olan Zeki Ketani Bey, 12 Şubat 1921 gecesi Türk öğrencilerin edebiyat kulübündeki bir toplantıdan çıkmış evine giderken, Kolej kapısından sadece bir blok ötede kendisine ateş edilir ve 24 saat içerisinde de ölür. 16 Şubat'ta hükumet konă̆ına çağrılan Amerikan misyonerleri, Ístiklâl Mahkemesi Başkanı Necati Bey ve Merzifon'a aktarılan 9. Ordu Kumandanı Cemil Cahid'le görüşür. Kendilerine Ketani cinayeti hakkında kantt toplamak, silah ve cephane aramak ve Türk hükumetine muhalif siyasi faaliyetleri ortaya çıkarmak için okulda arama yapılacağı söylenir. Toplantıdan sonra kampüse dönen misyonerler Kolej arazisinde çoktan 200'e yakın asker olduğunu ve aramanın başladığını görürler. Kolej ve hastaneyi arayan askerler ne silah ne de cephane bulur. Ancak okulda bulunan bazı haritalar ve kitaplar gerekçe gösterilerek kolejin Rumlar ve Ermeniler hesabına çalıştı̆̆ iddia edilir. İddiaya göre, okulda, Türkiye'nin Yunanistan'a katılacak kısımlarını gösteren harita ile Büyük Ermenistan ve Pontus haritaları bulunmuştur. Amasya Mutasarrıfi Osman Bey ve General Cemil Cahid, Dr. Marden ve Dr. White'i 18 Mart'ta tekrar görüşmeye çağırır. Kendilerine okulda Rumlar tarafindan Pontus adı altında siyasi propaganda faaliyeti yapıldı̆̆ının kanıtlandı ğ milli hükumete zarar verdiği söylenir. İki nöbetçi bırakılarak tüm kurumların kapatılması (Anadolu Koleji, Kız Okulu, Hastane) ve tüm Amerikalıların iki gün içerisinde şehri ve ülkeyi terk etmesi emredilir. Amerikalılar İstanbul'la temasa geçmek istediklerini söylerler ancak istekleri reddedilir. Neticede yirmi dokuz kişilik misyoner grubu 22 Mart 1921'de Merzifon'dan ayrllarak Samsun'a hareket eder. Oradan da gemiyle Istanbul'a geçerler. Okulun mallarına el konmuş ve ögrrenciler dăgıtılmıştır. 14 Mayıs 1921'de Amerika Fevkalade Komiserliği, İsveç Sefareti vasıtasıyla Hariciye Nezareti'ne bir protesto gönderir. Sorunun okulun tekrar açılması ve Amerikalıların Merzifon'a dönmesiyle çözülmesi talep edilir. Osmanlı Hükümeti'nin Ankara Hükumeti ile resmî münasebette bulunulmadığ gerekçesiyle talep reddedilir. Bunun üzerine okulun Selanik yakınlarında bir yere taşınmasına karar verilir". Nazan Maksudyan,

“Amerikan Kaynaklarında Merzifon Anadolu Koleji’nin Kısa Tarihçesi”, Kebikeç, Sayı 36, 2013, s. 147-148.

${ }^{51}$ Raporlar ve içeriği hakkında bilgi için bakınız; Arşiv Belgeleriyle Rum Faaliyetleri, s. 675, 677.

52 Gülbadi Alan (2001), "Protestan Amerikan Misyonerleri, Anadolu'daki Rumlar ve Pontus Meselesi”, Sosyal Bilimler Enstitüsü Dergisi, Sayı 10, 2011, s.204-205; Evsile, agm, s. 493.
} 
yaşanmıştır. ${ }^{53}$ Nakil sırasında görevini kötüye kullanan ve ihmalkâr davranan memurlardan birkaçı İstiklal Mahkemelerine teslim edilerek çeşitli cezalara çarptırılmışlardır. ${ }^{54} \mathrm{Bu}$ kapsamda yapılan diğer bir uygulama da daha önce bölgede Rum nüfus çoğunluğunu sağlamak amaciyla Samsun Rum metropolitliğine bağlı Göçmenler Komisyonu tarafından Rusya'dan ve Anadolu'nun iç kısımlarından getirilip yerleştirilmiş olan Rumların tekrar geldikleri bölgelere geri gönderilmeleridir. ${ }^{55}$ Sevke tabi tutulan kişilerin isimlerinin bir deftere yazılarak sevk edilmeleri, sevk sırasında firar eden veya hastalananların defterde künyelerinin karşısına işaret konulması ve sevk edilenlerin bırakıldıkları mahallin yetkililerine bilgi verilmesi gibi hususlar Merkez Ordusu Komutanı Nurettin Paşa tarafından 28.6.1921 tarihinde bir tebliğle yetki alanındaki Mutasarrıflıklara, Merkez ve Mıntıka Kumandanlıklarına bildirilmiştir. ${ }^{56}$ Merkez Ordusunun, Rumları iç bölgelere göç ettirme politikası sonucunda Amasya'dan gönderilen Rum sayıs1 14 bine ulaşmıştır. ${ }^{57}$ Asayişi ve düzeni bozucu eylemeleri önlemek için yapılan bu düzenlemeden maalesef istenen başarı elde edilememiştir. Konu, TBMM'nin gizli oturumda haylice tartışılmış, Pontus meselesinin bir türlü bitirilemeyişinin sebebi olarak Merkez Ordusu Komutanı Nurettin Paşa'nın izlediği politika gösterilmiş, uygulamaları eleştirilmiştir. ${ }^{58}$ Sürdürülen mücadelede başarısızlığa neden olan bir diğer kişi de Dâhiliye Vekili Fethi Bey gösterilmiştir. Tüm eleştirileri meclis genel kurulunda cevaplandıran Fethi Bey, bölgede bulunan kuvvetlerin gece gündüz demeden eşkıyayı takip ettiğini ve gerekli tedbirlerin alınarak mücadelenin sürdürüldüğünü ifade etmiştir. ${ }^{59}$

\section{2- Asayişi Sağlamak Üzere Kurulan Diğer Teşkilatlar}

Merkez Ordusunun kurulmasından önce bölgede asayiş ve güvenliği sağlanmak amacıyla yeni birtakım teşkilatların kurulması düşünülmüştür. Kurulan bu teşkilatların yapısı incelendiğinde çok geniş ve profesyonel bir yapıda olmadığı görülmektedir. Ancak o günün şartlarında bozguncu hareketleri engellemek ve düzeni muhafaza etmek amaciyla yeni teşkilatların kurulması gerekli görülmüştür. Faydalı olacağı düşünülen bu teşkilatların kuruluş ve amaçları hakkında aşağıda ayrıntılı bilgi verilmiştir.

\subsection{1- Asayiş Mıntıkaları Teşkilatı}

Sivas'taki 3. Kolordunun sorumluluk sahasında bulunan Amasya ve Tokat'in merkezden uzak nahiyelerinin sayıca fazla ve geniş bir alana yayılmış olması dolayısı ile asayişi sağlamakla görevli jandarma kuvvetleri zaman zaman yetersiz kalmıştır. Merkezden uzakta olmaları nedeniyle kontrolü zor olan bu yerlerde eşkıyalık olayları oldukça artmıştır. Bu sebeple 3 . Kolordu, asayişi temin etmek ve nahiyelerde kontrolü sağlamak üzere Asayiş Mıntıkaları

\footnotetext{
${ }^{53}$ Cengiz Çetintaş, TBMM Tutanaklarında Pontus Ísyanı ve Merkez Ordusu (1921-1923), 1. Bask1, 2018, s. 8.

${ }^{54}$ Çevik-Özkan, agm, s. 659.

55 Alan, agm, s. 204-205.

${ }^{56}$ Gedikli, age, s. 457

${ }^{57}$ Pehlivanll, agm, s.370.

58 TBMMGZC, C. 2, Devre 1, İçtima 2 101. Birleşim, s. 405; Lazistan Mebusu Ziya Hurşit Bey, Meclisin 29.10.1921 günkü gizli oturumunda, Nurettin Paşa'ya ağır eleştirilerde bulunmuştur. Paşa'nın beceriksizliğinden, Ordu Komutanı sıfatı ile en ufak teferruata kadar müdahale ettiğinden, fevkalade yetki kullandığından bahsederek ve bu kadar yetkiyi nerden aldığını sorgulayarak, Meclis-i Ali'nin derhal görevden almasını istemiştir; Benzer şekilde Trabzon mebusu Hafız Mehmet Efendi de 5.10.1921 tarihli meclisin gizli oturumunda bölgede yaşanan olaylar karşısında "Nurettin Paşa bu olayları yalnız harita üzerinde tetkik ediyor" sözleri ile eleştiride bulunmuştur (TBMMGZC, C. 2, s.284).

${ }^{59}$ Çevik-Özkan, agm, s. 659.
} 
Teşkilatı'nın kurulmasını uygun görmüştür. Ancak yeni kurulan teşkilat, 3. Kolordunun sorumluluk alanında yaygınlaştırılmak istenmişse de bu mümkün olmamıştır. Merkez Ordusu'nun kurulmasından sonra Mıntıka Komutanlıklarının oluşturulması üzerine, Asayiş Mıntıkaları Teşkilatı gelişme imkânı bulamamış ve nihayet ihtiyaç kalmadığından lağvedilmiştir. ${ }^{60}$ Asayişin sağlanması ve bozguncu hareketlerin önlenmesi amacıyla kurulan teşkilatın ömrü fazla olmamış, Mıntıka Komutanlıkları daha işlevsel yapı ile uygulamaya dâhil edilmiştir.

\subsection{2- Oymak Teşkilatı}

Pontusçu çetelerin özellikle Samsun bölgesinde başlattıkları saldırı ve çetecilik faaliyetlerine karşı tedbir olmak üzere Kavak, Bafra ve Çarşamba mıntıkasında Oymak Teşkilatı kurulmuştur. Teşkilatın, başına buyruk hareket etmemesi ve halka baskıda bulunmaması için Dâhiliye Vekâleti, 8 Ocak tarihinde bir tebliğ yayınlamış, teşkilatın mülkî memurlar ve jandarmanın emrinde faaliyet göstermesinin daha uygun olacağını duyurmuştur.

Merkez Ordusunun kurulması üzerine bölgedeki Rum çeteleri ile mücadelenin kurulan yeni ordu ile yapılması ve ciddi tedbirlerin alınması üzerine Oymak Teşkilatı'nın işlevi azalmıştır. Diğer taraftan bölgede asayişi temin için Emniyet Teşkilatı adı ile yeni bir yapılanmaya gidilmiştir. Bu teşkilatın devreye sokulması ile de 24 Haziran 1921 tarihinde Oymak Teşkilatı lağvedilmiştir. ${ }^{61}$

\subsection{3- Asayiş Bölükleri}

Volume 12

Merkez Ordusunun kurulması ve çalışmalarına başlaması üzerine özellikle ordu birliklerinin yerleştirildiği bölgelerden uzakta kalan sancak ve kazalarda asayişin sağlanması ve bozguncu hareketlere karşı tedbir almak amacıyla 100-200 kişiden oluşan Asayiş Bölüklerinin kurulması düşünülmüsstür. Bu maksatla Merkez Ordusu Komutanlığı, 26 Mart 1921 tarihinde Müdafaa-1 Milliye Vekâletine konu ile ilgili yazı göndermiş, vekâletten cevap beklenmeden Asayiş Bölüklerinin kurulmasına girişilmiştir. ${ }^{62}$

Asayiş Bölüklerinin oluşturulması, iaşe ve silahlarının temini, nerede ve nasıl kurulacakları, bölük komutanlarının seçilmesi gibi hususlarda her mıntıkada olmasa da bazı yerlerde zorluklarla karşılaşılmıştır. Merkez Ordusu, Asayiş Bölüklerini oluşturmaya çalışırken 8 Nisan tarihinde Müdafaa-1 Milliye ve Dâhiliye Vekâletinden Asayiş Bölükleri yerine bölgede Süvari Jandarma Birliğinin oluşturulmasının düşünüldüğü tebliğ edilmiştir. Bu kapsamda Amasya'da 400 kişilik süvari jandarma birliğinin oluşturulacağı ve bu birlik için lazım gelen erlerin Müdafaa-i Milliyece temin edileceği ifade edilerek bu hususta gerekenin yapılması istenmiştir. Merkez Ordusu Komutanlığı bu emirin gereğini yapacağını bildirmiş, ancak Asayiş Bölüklerini kurmaya devam etmiştir. Asayiş Bölükleri, Merkez Ordusu'nun sorumluluk alanında 9 bölgede oluşturulmuş, Amasya ve Tokat mıntıkasında da kurma çalışmalarını sürdürmüştür. Ancak, eksiklikler giderilemediğinden sonuç başarısız olmuştur. Diğer bölgelerde kurulan Asayiş

\footnotetext{
${ }^{60}$ Balcıoğlu, "Milli Mücadele Sirasında Merkezi Anadolu'da Asayişi Sağlamak İ̧̧in Oluşturulan Milis Kuruluşları", s. 262.

${ }^{61}$ agm, s 264.

62 agm, s 265.
} 
Bölükleri, kısa bir süre sonra Müdafaa-1 Milliye Vekâlet'inin ilgili birimlere yazdığı 9 Mayıs 1921 tarihli yazıları ile Mürettep Alay adı ile 3 taburdan oluşan birlikler haline getirilmiştir. 9 Asayiş Bölügünden oluşan Mürettep Alay bir süre sonra Batı Cephesi'ne sevk edilmiştir. ${ }^{63}$ Asayiş Bölüklerinin kurulmadığı bazı yerlerde bu birliklerin yerini yeni kurulan Emniyet Teşkilatı almıştır.

\subsection{4- Emniyet Teşkilatı}

Batı Cephesinde Yunanlılara karşı sürdürülen mücadele devam ettiği sırada aynı zamanda Karadeniz Bölgesi'nde Pontus çetelerinin eylemlerine karşı Merkez Ordusu Komutanlığı, başta askeri önlemler olmak üzere yasal yöntemlerle asayiş sorununu çözmeye çalışmıştır. Yukarıda sıraladığımız teşkilatların, komutanlık sorumluluk sahasında her mıntıkada kurulamaması veya etkili olmayışı nedeniyle yeni teşkilatların kurulmasına ihtiyaç duyulmuştur. Emniyet Teşkilatı da bunlardan biridir. Merkez Ordusu emrindeki, 5. ve 15. Firkalar ile 14. Süvari Alay1 ve 3 taburdan oluşan Mürettep Alayın Batı Cephesine sevk edilmesi üzerine özellikle Pontus bölgesi olarak tanımlanan bölgede Rum çetecilerinin bozguncu ve eşkıyalık faaliyetlerinin önüne geçilmesi zorlaşmıştır. Bunun üzerine Nurettin Paşa, 24 Haziran 1921 tarihinde ilgili birimlere gönderdiği yazısında komutanlık sınırları içindeki toplam 11 sancaktan öncelikli olarak Sivas, Çorum, Yozgat ve Ordu'da Emniyet Teşkilatı adıyla bir teşkilat kurulacağını emretmiştir. Emniyet Teşkilatı'nın kurulacağı sancaklara daha sonra Samsun, Tokat ve Amasya da dâhil edilmiştir. ${ }^{64}$

Teşkilatın özellikle eşkıya takibinde kullanılması ve komutanlarının da ihtiyat subaylarından veya eşraftan olması düşünülmüştür. Görev ve sorumlulukların neler olduğunu tanımlayan bir de Emniyet Teşkilatı Talimatnamesi yayınlanmıştır. Buna göre teşkilatın görevi;

“Emniyet ve asayişi sağlamak, hırsızlı̆̆ önlemek, asker firarilerini ve halkı iğfal eden muzır propagandacıları yakalamak, siyasi eşkıyayı ve asileri ortadan kaldırmak ve icap ettiğinde vatanın kurtarılması için düşmanlarla muharebe etmek"

olarak tanımlanmıştır. Kurulacak Emniyet Teşkilatı'nın hükümete bağlı olarak kendi mıntıkasında mülkî kanunlara, dışarda ise askeri hizmet ve hükümlere tabi olacağı belirtilmiştir. ${ }^{65}$

Emniyet Teşkilatı'nın oluşturulmasında bazı sorunlar yaşanmıştır. Bazı sancaklarda teşkilatın kurulması, Merkez Ordusu Komutanı Nurettin Paşa'nın keyfi uygulaması olarak değerlendirilerek mantıklı görülmemiştir. Ordu, Yozgat, Tokat, Vezirköprü ve Erbaa'da teşkilatın kuruluşu gerçekleşmiştir. Asayişin tesisi, eşkıya ile mücadele edilmesi ve düzenin muhafazası başta olmak üzere Millî Mücadele ruhunun halka yayılmasını temin etmek amacını taşıyan Emniyet Teşkilatı'nın Pontusçu faaliyetlere karşı da yararlılıkları görülmüştür. ${ }^{66}$ Merkez

\footnotetext{
63 agm, s 268.

${ }^{64}$ agm, s 269-270.

${ }^{65}$ agm, s. 269-270; Talimatnamenin giriş kısmında, "Emniyet ve asayiş-i dâhiliyenin temin ve muhafazasına muavenet, siyasi eşkıyay tedip ve tenkil, dâhili isyan ve iğtişaş zuhurunda men ve itfasina hizmet etmek ve kazalarda, köylerde yollarda, yaylalarda, meralarda velhasıl dâhili memlekette hırsızlı̆̆l ve her fenalı̆̆ men ve ahalinin can, ırz ve malını elbirliği ile muhafaza, hırsızları işrayı, asker firarilerini ve halkı ifsat eden propagandacıları hükümet kuvveti ile müştereken derdest eylemek üzere Emniyet Teşkilatı namında bir teşkilat vücuda getirilecektir" ifadesi yer almıştır. Teşkilatın işlevi, görev ve sorumlulukları talimatnamenin diğer kısmında açılanmıştır.

${ }^{66}$ agm, s 274.
} 
Ordusu Komutanı olarak Nurettin Paşa yaklaşık bir yıl bu görevde bulunmuştur. 1921 Kasım ayı sonlarında görevinden alınmıştır. ${ }^{67}$ Paşa'nın görevden alınması ile de Emniyet Teşkilatı lağvedilmiştir. ${ }^{68}$

\section{3- Amasya'da Sıkıyönetim İlanı ve İstiklal Mahkemesinin Kurulması 3.1- Sıkıyönetim İlanı}

Pontus Meselesi hakkındaki kaynaklarda ve konu üzerinde yapılan çalışmalarda, Millî Mücadele Döneminde Amasya ve çevresinde Rumların örgütlenerek asayişi ve düzeni bozdukları, eşkıyalık yaptıkları, Müslüman ahaliye yönelik gasp, tecavüz, yağma, yakma ve öldürme olayları ile merkezi otoriteye karşı eylemlere giriştikleri, nihayet yasa dışı davranışlarda bulundukları ortaya konmuştur. Bölgede yaşayan Müslüman ahalideki hoşnutsuzluk ve merkezi hükümetin bu durumdan duyduğu rahatsızlık nedeniyle yukarıda söz edildiği üzere Merkez Ordusu kurularak, komutanlığına Nurettin Paşa atanmıştır. Ordu komutanı sıfatı ile Nurettin Paşa, 1921 yılı Şubat ayında gerek Erkan-1 Harbiye Umumi Riyaseti'ne, gerek Müdafaa-1 Milliye Vekâletine gerekse Dâhiliye Vekâletine Amasya ve havalisindeki Rum eşkıyalarının faaliyetleri, eylemleri ve onlara karşı alınan tedbirler hakkında raporlar göndermiş̧ir. Bu raporlar TBMM tarafından değerlendirilmiş, nihayetinde 5 Mart 1921 tarihinde konu Bakanlar Kurulunda görüşülerek Amasya sancağında sıkıyönetim ilan edilmesine karar verilmiştir. ${ }^{69}$ Hazırlanan kararnamenin içeriği şöyledir:
"Pontus meselesinin hızlı ve kesin şekilde sonuçlanması ülkenin menfaati gereğidir. Bundan başka siyasi suç işleyenler ile terörist eylemlerde bulunanların yargılanmaları ve haklarında kanun hükümlerinin hızla uygulanarak yaptıkları zararlı işlerin ortadan kaldırılması gerektiğinden Yozgat Sancă̆ hariç olmak üzere Merkez Ordusu Komutanlı̆̆l bölgesinde sıkıyönetim ilan edilmesi lüzumu Millı̂ Savunma Bakanlı̆̆ının 2 Mart 1921 tarih ve 552 sayılı yazısında bildirilmiştir. Durum Bakanlar Kurulunun 5 Mart 1921 tarihindeki toplantısında değerlendirilmiş ve silah toplanması sırasında genel emniyetin sağlanması amacıyla Ordu, Canik, Tokat, Amasya ve Çorum sancaklarında sıkıyönetim ilanı kararı alınmıştır”. 70

S1kıyönetimin ilanı ile Pontusçu eylemeleri önlemeye yönelik yeni bir adım atılmıştır. Kanunun yürürlüğe girmesi ile Merkez Ordusu Komutanı Nurettin Paşa, sorumluluk alanında kanununun sağladığı imkân ve avantajla daha etkin hareket etmiş radikal kararlar almıştır. Ancak Paşa'nın, sahada bir kısım uygulamaları sebebiyle mecliste ağır eleştirilere maruz kalmıştır. Sıkıyönetim uygulamasının olayların önlenmesinde etkili olduğu kabul edilebilir. Ancak sorunu kökten çözücü bir yanı olmamıştır. Sıkıyönetim uygulaması yaklaşık 7 ay sonra, 27 Ekim 1921 tarihinde kaldırılmıştır. ${ }^{71}$ Tüm bunlar, bölgede yaşanan huzursuzluğun etkisinin büyük olduğunu, o günün zor şartlarında huzursuzluğun bertaraf edilmesi için hükümetin ciddi adımlar atmak ve önlemler almak zorunda kaldığını göstermektedir.

\footnotetext{
${ }^{67}$ Nutuk, s. 427.

${ }^{68}$ Balcığlu, agm, s. 274.

${ }^{69}$ BCA (Devlet Arşivleri Başkanlığı Başbakanlık Cumhuriyet Arşiv Kararlar Daire Başkanlığı), 30.18.1.1/2.38.2

${ }^{70}$ Arşiv Belgeleriyle Rum Faaliyetleri, (Sıkıyönetim ilanını ilişkin Bakanlar Kurulu Kararı sureti, Türkiye Büyük Millet Meclis Başkanı Mustafa Kemal'in mühür ve imzası ile yayınlanmıştır) s. 325.

${ }^{71}$ BCA, 030.18.1.1/4.39. 9
} 


\section{2- Amasya İstiklal Mahkemesinin Kurulması}

TBMM açıldıktan hemen sonra meclisin çalışmalarını engelleyen, alınacak kararlara uymayan kimseleri cezalandırmak ve tepkileri engellemek amacıyla 29 Nisan 1336 (1920) tarihinde 14 maddeden oluşan Hıyanet-i Vataniye Kanunu kabul edilmiştir. ${ }^{72}$ Hıyanet-i Vataniye Kanununun asayişin sağlanması, firarilerin önlenmesi ve onların yarattığı olumsuz etkileri ortadan kaldırmakta yeterli olmaması üzerine daha etkili olacak ve bu konudaki endişeleri giderecek yeni bir kanun çıkarılması düşünülmüsşür. Bu amaçla 2 Eylül 1920 tarihinde Firariler Hakkında Kanun'a ilişkin layiha ve gerekçesini içeren Müdafaa-1 Milliye Encümeni Mazbatası hazırlanmıştır. ${ }^{73}$ Hazırlanan kanun layihası meclis genel kurulunda ele alınmış, katkı sağlayacak fikir ve düşünceler ile olumlu olumsuz yönde yapılan tartışmalardan sonra 11 Eylül 1920 günü kanun kabul edilmiştir. ${ }^{74}$

Kanun 9 maddeden oluşmaktadır. Kanunda özetle; askerden kaçanlarla onlara yardım ve yataklık edenlerin yargılamalarını yapmak üzere üyeleri Büyük Millet Meclisi üyelerinden oluşacak İstiklal Mahkemelerinin kurulacağı ifade edilmekte; mahkemelerin meclis tarafından seçilecek üç üyeden oluşacağı; nerede ve hangi sayıda kurulacağının hükümetin teklifi üzerine meclis tarafindan belirleneceği; bu mahkemelerin kararlarının kesin olacağı ve infazı ile bütün devlet güçlerinin görevli olacağı; mahkemelerin emir ve kararlarına uymayanların veya infazda tereddüt gösterenlerin aynı mahkemeler tarafından yargılanarak cezalandırılacağı belirtilmiştir. $\mathrm{Bu}$ kapsamda mecliste görüşmeler yapılmış, nihayet 18 Eylül'de yapılan toplantıda meclis kararıyla İstiklal Mahkemelerinin acil olarak Ankara, Eskişehir, Konya, Isparta, Sivas, Kastamonu ve Kayseri olmak üzere 7 bölgede kurulmasına karar verilmiştir. Birinci Dönem İstiklal Mahkemeleri olarak adlandırılan bu mahkemeler, yaklaşık 4 ay görev yaptıktan sonra beklenen sonucun alınması üzerine (Ankara İstiklal Mahkemesi hariç) TBMM'nin 97 sayılı kararı ile 17 Şubat 1921 tarihinde kapatılmıştır. ${ }^{75}$ Bu süreçte Amasya'da bir İstiklal Mahkemesi henüz açılmamıştır. Ancak Sivas İstiklal Mahkemesinin bazı yargılamaları Amasya'da yapılmıştır. Birinci Dönem İstiklal Mahkemelerinin kapatılmasından kısa bir süre sonra firar, casusluk, gasp, bozgunculuk ve soygunculuk gibi hadiseler artmış, genel asayiş ve düzen bozulmaya başlamıştır. Asayişin bozulması ve özellikle Amasya civarında Pontusçu Rumların olumsuz faaliyetleri mahkemelerin kurulmasını yeniden gündeme getirmiştir. Amasya ve havalisinde bu bağlamda yaşanan sıkıntılar, Merkez Ordusu Komutanı Nurettin Paşa tarafından Erkan-1 Harbiye Umumi Riyaseti'ne 25 Şubat 1921 tarihinde gönderilen yazı ile anlatılmıştır. Nurettin Paşa'nın Erkan-1 Harbiye Umumi Riyaseti'ne gönderdiği yazıda özetle: Pontus Cemiyeti üyesi Rumların faaliyetlerine devam ettikleri, Müslüman ahalinin yaşadığı yerlerde karışıklıklar çıkardıkları, ihanet içinde bulunanların tutuklandıkları, silahların toplatılması gibi tedbirlere başvurulduğu, Pontus meselesinin hızlı ve kesin şekilde sonuçlanması gerektiği, bunun devletin yararına olacağı, siyasi suç işleyenlerle beraber halen terörist eylemlere devam

${ }^{72}$ Düstur, Üçüncü tertip, C. 1, s. 4.

${ }^{73}$ Istiklal Mahkemeleri, s. 2-3.

${ }^{74}$ T.B.M.M. Kavanin Mecmuası, Devre I, C. 1, s. 22; Düstur, s. 61

${ }^{75}$ Rahmi Çiçek, "Kastamonu İstiklâl Mahkemelerinin Bölgede Güvenlik ve Asayişin Sağlanmasındaki Rolü”, İstiklal Mahkemeleri, (İstiklâl Mahkemeleri Sempozyumu, 10-11 Aralık 2015- Adıyaman), Atatürk Araştırma Merkezi Yayınları, Ankara 2016, s. 211. 
edenlerin yargılanmaları gerektiği, bunun için de Samsun, Ordu ve Amasya Sancakları için Amasya'da bir Divan-1 Harb-i Örfi'nin (Sıkıyönetim Mahkemesi) kurulması için emir buyurulması teklif edilmiştir. ${ }^{76}$

Bu talep üzerine Amasya'da hemen bir Sıkıyönetim Mahkemesi kurulmamış ise de genel asayişin bozulduğu yerler olarak görülen başta Konya, Kastamonu ve Pontusçu eşkıyaların eylemlerinin görüldüğü Samsun'da İstiklal Mahkemesi'nin kurulmasına karar verilmiştir. 23 Temmuz 1921 tarih ve 140 numaralı Meclis Kararıla Kastamonu, Konya ve Samsun'da İstiklal Mahkemeleri kurulmuştur. ${ }^{77} 8$ Eylül 1921 tarihinde Mustafa Kemal Paşa'nın gördüğü lüzum üzerine Eskişehir ve Yozgat'ta da İstiklal Mahkemesi kurulmuştur. Bundan sonra Tekâlif-i Milliye Emirlerine uymayanlar ile Pontusçuluk faaliyetlerinde bulunanların cezalandırılması da bu mahkemelerin görev alanına girmiştir. ${ }^{78} \mathrm{Bu}$ dönem açılan İstiklal Mahkemeleri, İkinci Dönem İstiklal Mahkemeleri olarak adlandırılmıştır. Bu mahkemelerin faaliyetlerine ise 1 Ağustos 1922 tarihinde 274 nolu Meclis kararıly son verilmiştir. ${ }^{79}$

İstiklal Mahkemelerinin kuruluş ve faaliyetleri hakkında bilgi veren çalışmalarda Amasya İstiklal Mahkemesi hakkında doğrudan doğruya veya ayrıntılı bilgiye rastlanmamıştır. Bununla birlikte konu ile ilgili yaptığımız araştırmada, yukarıda sözünü ettiğimiz İstiklal Mahkemelerinin yükümlülügünde olmasa bile Amasya' da bir İstiklal Mahkemesi kurulması çalışmaları yapıldığg, uzun süre görevde kalmamakla birlikte mahkemenin kurulduğu, konunun mecliste gizli oturumlarda görüşüldüğü, üye seçimine ilişkin tartışmaların olduğu ve mahkeme üyelerinin seçildiğine ilişkin bilgilerin varlığı Amasya'da bir İstiklal Mahkemesinin kurulduğunu göstermektedir. ${ }^{80}$ Ayrıca TBMM arşivinde bulunan 12 İstiklal Mahkemesinin belgeleri arasında Amasya İstiklal Mahkemesinin evraklarının bulunması, bu konudaki tereddütleri ortadan kaldırmaktadır. Arşivde bulunan İstiklal Mahkemelerine ait 26 adet defter TBMM Başkanlığı'nın onay1 ile "İstiklal Mahkemeleri, Tasnif, İndeks ve Elektronik Ortama Aktarma" projesi çalışmaları kapsamında Osmanlıcadan Türkçeye çevrilmiştir. Bu proje çalışmalarında Amasya İstiklal Mahkemesinden de söz edilmektedir. ${ }^{81}$ Tüm bu veriler kısa süreli olsa da Amasya'da bir İstiklal Mahkemesinin kurulduğunu ve faaliyet gösterdiğini kanttlamaktadır.

Birinci Dönem İstiklal Mahkemeleri olarak tanımladı̆̆ımız mahkemelerden Sivas'ta kurulan mahkemenin görev alanı içinde Sivas vilayeti, Samsun ve Tokat'la birlikte Amasya livası da yer almıştır. Henüz bu ilk devre mahkemeler arasında Amasya'da bir resmî mahkeme kurulmuş olmamasına rağmen Sivas İstiklal Mahkemesinin yargılamalarının ve çalışmalarının Amasya'da yapılmış olması dolayısı ile genellikle Sivas İstiklal Mahkemesi, resmî kayıtlarda Amasya

\footnotetext{
${ }^{76}$ Arşiv Belgeleriyle Rum Faaliyetleri, s. 320.

77 Istiklal Mahkemeleri, s. X.

${ }^{78}$ Riza Zelyut, İstiklal Harbi'nin Hukuk Cephesi İstiklal Mahkemeleri (Meclis Tutanaklarl), I. Baskı, Kripto Basım Yayım Dağıtım, Ankara 2017, s. 27.

${ }^{79}$ Düstur, C. 3, s. 110; İstiklal Mahkemeleri, s. X. (İkinci Dönem İstiklal Mahkemelerinin açık bulunduğu süreyi 30 Temmuz 1921-Ekim 1923 olarak gösteren çalışmalar da bulunmaktadır. Tarihlendirme için bakınız; Mukaddes Arslan, “İstiklal Mahkemeleri Belgelerinin Kamuoyuna Açılma Sürecinde T.B.M.M. Arşivi”, İstiklal Mahkemeleri, (İstiklâl Mahkemeleri Sempozyumu, 10-11 Aralık 2015- Adıyaman), Atatürk Araştırma Merkezi Yayınları, Ankara 2016, s. 89).

${ }^{80}$ T.B.M.M Gizli Celse Zabitları, Devre I, C. 3, s. 634-637.

${ }^{81}$ Arslan, agm, s. 89.
} 
İstiklal Mahkemesi olarak geçmiştir. ${ }^{82}$ Dolayısı ile Amasya'da resmî olarak bir mahkeme kurulmadan önce burada İstiklal Mahkemelerini ilgilendiren davalara bakıldığı ve yargılama yapıldığı anlaşılmaktadır. İlk dönem İstiklal Mahkemelerinin kapatılmasından bir müddet sonra Amasya, lüzum üzere yeniden açılan İkinci Dönem İstiklal Mahkemelerinden Samsun İstiklal Mahkemesinin çalışma bölgesi içinde yer almıştır. Samsun İstiklal Mahkemesi de Sivas İstiklal Mahkemesi'nde olduğu gibi çalışmalarını Amasya'da yaptığı için resmî kayıtlarda Amasya İstiklal Mahkemesi olarak geçmiştir. Mustafa Kemal Paşa bölgenin hassasiyeti dolayısı ile mahkemenin Amasya'da kalmasını istemiştir. ${ }^{83}$ Samsun İstiklal Mahkemesi ve onunla kurulan diğer İstiklal Mahkemeleri, 31 Temmuz 1922 tarihinde 249 sayılı kararla "İstiklal Mehakimi Kanunu" kabul edildikten sonra, 1 Ağustos 1922 tarihinde faaliyetleri sona ermiştir. Ancak bu mahkemeler kapatılmadan kısa bir süre önce 27 Temmuz 1922 günü Amasya bölgesi için yeni bir İstiklal Mahkemesinin teşkiline ilişkin İcra Vekilleri Tezkeresi meclise sunulmuştur. ${ }^{84}$ Amasya'da İstiklal Mahkemesi kurulmasına ilişkin tezkere üzerinde tartışmalar meclis gündemini bir hayli meşgul etmiştir. Amasya'da İstiklal Mahkemesinin kurulmasına gerek olmadığını ileri sürenler olduğu gibi özellikle Pontusçu faaliyetlere girişenlerin cezalandırılması için mahkemenin kurulmasının faydalı olacağını ifade eden vekiller de olmuştur. Nihayet meclisin 26 Temmuz 1922 tarihli gizli oturumunda, Mahkemenin kurulmasına yönelik lehte ve aleyhte yapılan tartışmaların ardından Meclis Başkanlığına bir kısım vekiller tarafından Amasya'da bir İstiklal Mahkemesi kurulmasına, kurulacak mahkemenin yalnızca Pontusçuluk faaliyetlerine ve asker firarilerine ait davalara bakmalarına, üyelerinin 3 ayda bir seçilmelerine yönelik önergelerin verilmesi ile oturum tamamlanmıştır. ${ }^{85}$ Bir sonraki gün yapılan toplantıda İcra Vekilleri Başkanlığınca hazırlanan "Yeni Bir İstiklal Mahkemesi Teşkiline Dair İcra Heyeti Tezkeresi" meclis gündeminde ele alınmıştır. Sonuçta Amasya'da İstiklal Mahkemesinin kurulmasına ilişkin olumlu ve olumsuz görüşlerin paylaşıldığı müzakereler sonunda Amasya'da 27 Temmuz 1922 tarihinde İstiklal Mahkemesi kurulmuştur. ${ }^{86}$ Böylece yalnız Pontusçu faaliyetler ile asker firarilerine ilişkin davalara bakmak üzere mahkeme üyelerinin de Heyet-i Vekile'nin teklifi ile seçilip tespit edilmesi esasları doğrultusunda Amasya İstiklal Mahkemesi'nin kuruluşu gerçekleşmiştir. Müstakil olarak Amasya İstiklal Mahkemesi yaklaşık bir ay görev yapmıştır. Mahkeme üyeleri 16 Eylül 1922 günü görevlerinden istifa etmişlerdir. Bundan sonraki süreçte üyelerin yeniden seçilmesi için yapılan toplantıda bir türlü sonuç alınamamış, mahkemeye yeni üyeler seçilememiştir. Mecliste bu konu üzerinde tartışmalar sürerken diğer taraftan bu günlerde, ordu Büyük Taarruz ve Başkomutanlık Muharebeleri ile Yunan kuvvetlerini bozguna uğratmış, büyük bir zafer kazanılmıştır. Türk Ordusunun Büyük Taarruz başarısı ve Yunan Ordusunu kesin yenilgiye uğratmasının yarattığı etki üzerine TBMM'de İstiklal Mahkemelerine artık ihtiyaç kalmadığı yönünde görüşler belirmeye başlamıştır. Mecliste konu üzerinde lehte ve aleyhte yapılan tartışmalardan sonra Dâhiliye Vekili Ali Fethi Bey, 27 Kasım 1922 günü tartışmalara son verecek bir açıklamada bulunmuştur. Açıklamasında;

82 Aybars, age, s. 94.

83 Age, s. 126-127.

${ }^{84}$ TBMMGCZ, Devre I, C. 3, s. 634.

85 TBMMGCZ, Devre I, C. 3, s. 627.

${ }^{86}$ Ístiklal Mahkemeleri, s. 7. 
"Pontus eşkıyası tedip edildiğinden Amasya İstiklal Mahkemesi’ne lüzum kalmadı̆̆ını, esasen istifa edenlerin yerine seçim yapllamamasının da bunu gösterdiğini”"

ifade etmiştir. ${ }^{87} \mathrm{Bu}$ açıklamanın ardından Amasya İstiklal Mahkemesinin görevi fiilen sona ermiştir.

Sivas ve Samsun İstiklal Mahkemeleri'nin faaliyette bulundukları devrede bu mahkemelerin yargılamalarının Amasya'da yapılmış olması ve bu işlemlerin Amasya İstiklal Mahkemesi işlemleri olarak resmî kayıtlarda yer alması bağlamında mahkemenin yargılamalarından söz etmek mümkündür. Bu kapsamda söz konusu mahkemede, 20 Ekim 1920'den 15 Mart 1921 tarihine kadar geçen sürede tespit edilen suçlar ve verilen cezalar aşağıdaki listede gösterilmiştir. ${ }^{88}$

İşlenen Suçlar ve Dağılımı

\begin{tabular}{|l|l|}
\hline Casusluk & 7 Rum \\
\hline Yaralama & 3 \\
\hline Davete gelmemek & 4 Rum \\
\hline Eşkıyaya yardım & 43 (42'si Rum) \\
\hline Eşkıyayı himaye & 15 Rum \\
\hline Firar & 119 (100'ü Rum) \\
\hline Eşkıyaya katılma & 1 Rum \\
\hline Firar ve Haydutluk & 1 Rum \\
\hline Vatana ihanet & 1 \\
\hline Saklanma-Gizlenme & 13 \\
\hline Pontusçuluk & 119 Rum \\
\hline Rum çetelerine katılma & 39 Rum \\
\hline Sevke tabi Rum kadınlarını kaçırmak & 1 \\
\hline Haydutluk-Eşkıyalık & 2 Rum \\
\hline Şüpheli & 2 \\
\hline Görevi ihmal & \\
\hline
\end{tabular}

${ }^{87}$ Age, s. 3; Aybars, age, s. 140.

${ }^{88}$ Age, s. 94. 
Millı̂ Mücadele Döneminde Amasya ve Havalisinde Pontus Terörüne Karşı Alınan Tedbirler

Mahkemece Verilen Cezalar

\begin{tabular}{|l|l|}
\hline Mahkemeye gelen şüpheli sayısı & 280 \\
\hline Sorumsuzluk ve berat & 23 \\
\hline İdam & 12 \\
\hline Tecil edilmek suretiyle idam & 109 \\
\hline Gryabında idam & 1 \\
\hline Kalede yaşamaya mahkûm ve kürek cezası alan & 34 \\
\hline Muhtelif cezalarla mahkûm olanlar & 101 \\
\hline
\end{tabular}

\section{4- Amasya ve Havalisi Kuva-yı Takibiye Kumandanlığının Kurulması}

Millî Mücadele döneminde, genel olarak Doğu Karadeniz Bölgesindeki diğer sancak ve kazalar ile Amasya ve havalisinde baş gösteren Pontusçu Rumların bozguncu faaliyetlerini önlemeye yönelik yukarıda özetlemeye çalıştığımız tedbirlerin yanında, yine asayişi temin etme maksadıyla yeni bir askerî tedbirin alınması düşünülmüştür. Anlaş1lan tüm çabalara, alınan radikal karar ve uygulamalara rağmen Pontusçu Rumların eylemeleri büyük ölçüde önlenmiş olmakla birlikte tamamen bitirilememiștir. Durumun bu merkezde olduğunu, meclisin 24 Ağustos 1922 tarihinde gizli oturumundaki tartışmalardan anlayabilmekteyiz. Kütahya Mebusu Ragıp Bey konunun önemini ve ne yapmak lazım geldiğini;

“...Pontus Meselesi hadisatı fevkalâde hükmüne geçmiştir. Fevkalâde hadisata, fevkalâde tedabir ittihaz etmedikçe önüne geçmek imkânı yoktur... Meclisin vazifesi; tarih nazarında böyle bîsut (neticesiz) ve bî mana (manasız) mütalâa ile hadisatı ihmal etmek çok feci bir meseledir. Binaenaleyh bu hadiseye karşı tedabiri fevkalâde ittihaz ederek bir an evvel bunun halli lazımdır..."

cümleleri ile anlatmaya çalışmıştır. ${ }^{89}$ Benzer şekilde aynı oturumda söz alan Karahisar Mebusu Mehmet Şükrü Bey de Pontus meselesinde başarısız olunduğunu, başarısızlığın Hükümetin ve Dâhiliye Vekâletinin izlediği politikalar ile uygulamalara dayandığını belirtmiştir. Başarısızlığın nedenlerine işaret ettiği konuşmasında;

“...Pontus hadise ve vekayii cidden memleketimiz, üç livamızı bî hakkın bîzar etmiş, ateş ve felaket içinde bırakmıştır. Bunun içindir ki bugüne kadar oradaki şekaveti, oradaki yangını söndürmek için yapılan tedabir müessir olamamıştır. Bunun müessir olamamasını bendeniz Hükümetin bu işleri ciddiyetle takip etmemesinde görüyorum. Yani bugüne kadar Dâhiliye Vekâleti bu mesele hakkında layik olduğu veçhile malumat edinememiş ve layik olduğu derece bu işleri takip edememiştir..."

sözleri ile yeterli tedbirlerin alınmadığını, Dahiliye Vekâletinin üzerine düşen görevi layığ 1 ile yerine getirmediğini, kısaca ihmalkâr davrandığını belirtmeye çalışmıştır. Dolayısı ile konunun

${ }^{89}$ TBMMGCZ, Devre I, C. 3, s. 726. 
mecliste tekrardan görüşülerek gerekli tedbirlerin alınması gerektiğini vurgulamıştır. ${ }^{90} \mathrm{Bu}$ ithamlar üzerine dönemin Dâhiliye Vekili Ata Bey iddiaları cevaplandırmış, Vekâletin üzerine düşeni yaptığını, gerekli tedbirlerin alındığını, ancak bölgedeki jandarma kuvvetinin yetersiz geldiğini, bunun için 3 bin kişilik jandarma kuvvetinin ilavesini teklif ve talep ettiklerini, bunun verilip verilmeyeceğini bilmediğini, tüm bu hususları yüce meclise arzettiklerini ifade etmiştir. ${ }^{91}$ Dâhiliye Vekili Ata Bey'in mecliste yaptığı konuşmadan meselenin tamamen halledilmediği anlaşılmaktadır.

Meclisin bu oturumunda Pontus meselesinin çözümü ve alınacak tedbirler hakkında diğer mebusların da katılımı ile tartışmalar devam etmiştir. Konunun halen halledilememiş olması ve bölgede önemli derecede rahatsızlık yaratması yeni önlemler alınması gereğini ortaya koymuştur. Bu bağlamda önce 21Ağustos 1922 tarihinde "Takibi Eşklya Hakkında Kanun Layihası" hazırlanarak bölgede huzur ve asayişi ihlal eden eşkıya ve çetelerin takip, tenkil ve imhasını sağlama maksadı ile bu işte uzman veya askeriyeden olmak üzere bir başkanın nezaretinde 3 kişiden oluşan "Takip Heyet-i Fevkaladesi" (Olağanüstü Takip Heyeti) kurulmuştur. ${ }^{92}$

Ardından bununla yetinilmeyerek, Samsun, Amasya ve Tokat Sancaklarında geçici bir Kumandanlığın kurulması düşünülmüştür. Bu kapsamda meclisin 24 Ağustos 1922 günkü gizli oturumunda konu ele alınmış, hazırlanan "Pontus Meselesi Hakkında Layiha" mecliste okunarak müzakereye açılmıştır. Bu layihada Pontus Meselesi olarak tanımlanan bir meselenin varlığından söz edilmiş; eşkıyalık ve isyan hadiselerinin devam ettiği, bu tür eşkıyalık hadiselerinin önüne geçmek için tedbirler alınmasının gereğine işaret edilmiştir. Bu bağlamda Samsun, Amasya ve Tokat sancaklarında geçici bir kumandanlık kurulması ve buna memur edilmek üzere meclis üyelerinden bir kişinin seçilip tayin edilmesi ve bu görevliye refakat ve yardımda bulunacak 3 kişinin de TBMM tarafından seçilerek görevlendirilmeleri istenmiştir. Hazırlanan layihanın ilk maddesinde, Amasya ve havalisinde geçici Kuva-yı Takibiye Kumandanlığının kurulacağına işaret edilmiştir. Layihanın 1. Maddesinde;

"Canik, Amasya ve Tokat Sancaklarında vatanin tecazzisi, gaye-i hainanesini takiben icrayl, şekavet eden erbab-ı fesadın tenkiline ve huzur ve asayişin temin ve istikrarına müteallik umur ve vezaifle mükellef olmak üzere (Amasya ve Havalisi Kuva-yı Takibiye Kumandanlı̆̆l) unvanıyla muvakkaten bir kumandanlık ihdas edilmişstir"

denilerek, diğer maddelerinde de kumandanlığın görev, sorumluluk ve yetkilerinin neler olduğu belirtilmiştir. Bunların bazıları; asayişin ve istihbarat sağlanmasında sırf istişari olmak üzere komutanlığa yardımda bulunulacak; komutanlıkça verilecek vazifeyi yerine getirecek, eşkıyaya karşı gerekli tedbirleri alacaktır. Ayrıca, Kuva-yı Takibiye'nin teşkili ve bunun için gerekli bütçenin Müdafaa-1 Milliye bütçesinden karşılanması; kumandanlık emir ve kararlarının yerine getirilmesinde ihmal veya suiistimali olan memurların kumandanlığın talebine göre azledilmesi ve cezalandırması veya kumandanlığın bu kimseleri işten el çektirmesi gibi hususlar ile kanunun uygulanışından İcra Vekilleri Heyeti'nin sorumlu tutulacağı hükümleri yer almıştır. ${ }^{93}$

90 TBMMGCZ, Devre I, C. 3, s. 727-728.

91 TBMMGCZ, Devre I, C. 3, s. 727-728.

92 TBMMGCZ, Devre I, C. 3, s. 707.

93 TBMMGCZ, Devre I, C. 3, s. 711-713. 
Kanun taslağı meclis gizli oturumda olumlu ve olumsuz yönleri ile tartışılmıştır. Genellikle meclisten seçilen heyetin, İcra vekilleri karşısındaki konumu ile asayiş sorununda asıl sorumluluğu taşıyan Dâhiliye Vekâlet'inin yetkisi üzerinde tartışmalar yoğunlaşmıştır. Ayrıca yeni Jandarma birliklerinin oluşturulması ve onların iaşesi ve yetkilendirme sorunu da tartışılan konulardan bir diğeri olmuştur. Aleyhte görüş beyan edenlerin haylice etkili olması üzerine görüşmelerden bir sonuç elde edilememiştir.

1922 y1lı sonlarına doğru Batı cephesinde Yunanlılara karşı kazanılan başarılara bağlı olarak Pontusçu hareketlerde azalma hissedilmiştir. Diğer taraftan Giresun ve çevresinde Topal Osman Ağa'nın, Rum çetelerine karşı başlattığı mücadelenin de Karadeniz Bölgesinde elde edilen başarıda önemli bir yer tuttuğunu söyleyebiliriz. ${ }^{94}$ Amasya ve havalisinde Rum çetecilere karş1 yürütülen mücadelede istenen ölçekte olmasa de alınan tedbirlerle belirli bir mesafe kat edilmiştir. Bir kısım Rumlar çareyi göç etmekte bulmuşlar, getirilen kısıtlamalara rağmen İstanbul, Yunanistan ve başka ülkelere göç etmişlerdir. Mudanya Anlaşmasının imzalanmasından yaklaşı 1 ay sonra, 8 Kasım 1922'de Hristiyanların Anadolu'yu serbestçe terk edebileceklerinin duyurulması üzerine göç edenler olmuştur. ${ }^{95}$ Meselenin çözüme kavuşturulması, Lozan'da Türk ve Yunan tarafları ile 30 Ocak 1923'de yapılan "Türk ve Rum Nüfus Mübadelesine İlişkin Sözleşme ve Protokol'ün” imzalanması mümkün olmuştur. Tamamı 19 madde olan ve Lozan Antlaşması'nın bir parçası sayılacak bu sözleşmeye göre;

“Türk topraklarında yerleşmiş Rum Ortodoks dininden Türk uyruklar ile Yunan topraklarında yerleşmiş Müslüman dininden Yunan uyruklarının, 1 Mayıs 1923 tarihinden başlayarak zorunlu mübadelesine girişilecektir. Bu kimselerden hiçbiri, Türk Hükümeti'nin izni olmadıkça Türkiye'ye, ya da Yunan Hükümeti'nin izni olmadıkça Yunanistan'a dönerek orada yerleşemeyecektir". 96

Sözleşmenin diğer maddeleri bu mübadelenin nasıl ve ne şekilde yapılacağına ilişkindir. Uygulanmasında bazı uyuşmazlıklar yaşanmışsa da sonuçta Pontus Meselesi olarak adlandırılan konu diplomasi yöntemleri ile kesin çözüme kavuşturulmuştur.

\section{Sonuc}

Osmanlı Devleti zamanında sağlanan imkânlarla yüzyıllarca mesut ve müreffeh bir hayat süren Rumlar, devletin gücünün azaldığg dönemde dışardan aldıkları destek ve yardımlarla, yaşadıkları bölgelerde huzursuzluk yaratarak mevcut düzeni ve asayişi bozucu eylemlere girişmişlerdir. $\mathrm{Bu}$ eylemlerini ve mücadelelerini Tarihi Pontus Devletini yeniden kurmaya dayandırmışlardır. Amaçlarını gerçekleştirmek için kurdukları çetelerle, yoğunlukla yaşadıkları Doğu ve Orta Karadeniz Bölgesinde Türk ve Müslüman ahaliye insanlık dış1 davranışlarda bulunmuşlardır. Rum çetelerinin eylemleri Türk ahaliyi göçe zorlama, malını gasp etme, öldürme, yaralama, yakma, soygun ve tecavüz şeklinde görülmüştür. Güvenliği ve asayişi bozan Rumların bu örgütlü hareketleri Birinci Dünya Savaşında ve sonrasında Millî Mücadele

\footnotetext{
${ }^{94}$ Kilıç, agm, s. 499.

${ }^{95}$ Çevik- Özkan, agm, s.661

${ }^{96}$ Rifat Uçarol, Siyasi Tarih, Filiz Kitabevi, İstanbul 1995, s. 556.
} 
döneminde de devam etmiştir. Hükümet ve ilgili bakanlıklar bu bozguncu faaliyetlere karş1 gerekli önlemleri almaya çalışmıştır.

Pontusçu Rumların sözde ideallerini gerçekleştirmeye çalıştıkları ve bu amaçla eylemlerde bulundukları bölgelerden biri de Amasya ve havalisi olmuştur. Bu bölgedeki eylemleri hakkındaki bilgiler, gerek Merzifon'daki Amerikan Koleji ile ilgili tutulan raporlardan, gerekse Amasya Sancağı, Merzifon, Gümüşhacıköy, Gümüş Madeni nahiyesi ile Havza, Lâdik ve Erbaa kazalarında gerçekleştirdikleri öldürme, yaralama, yakma, taciz, ırza geçme, gasp ve göçe zorlama olaylarının yer aldığı cetvellerden elde edilmiştir. Ayrıca Merkez Ordusu komutanı Nurettin Paşa'nın Müdafaa-1 Milliye Vekâletine gönderdiği şifreli raporlardan ve diğer belgelerden yöredeki Rumların yarattı̆ğ tehdit ve tehlikeleri öğrenmekteyiz. Tüm bu veriler Pontus ideali ile hareket eden Rumların, Amasya mıntıkasında 1919-1922 yıllarında ciddi sorunlar yarattığını göstermektedir.

Bu durumda bölgede yaşanan olumsuzlukların giderilmesi, sükûnetin sağlanması, asayişin ve güvenliğin tesis edilmesi ile suçlu görülenlerin cezalandırılması için tedbirlerin alınmasına ihtiyaç duyulmuştur. Konu TBMM'de gündeme getirilmiş, meclisin gizli oturumlarında yapılması gerekenler ile alınması faydalı olacak tedbirlerin neler olabileceği üzerinde uzun uzun tartışmalar yapılmıştır. Tüm bu çaba ve çalışmalar sonunda Pontusçu faaliyetleri tamamen sona erdirmek amacıyla yasal düzenlemeler yapılarak, uygulamaya koyulmuştur. Bunlar; olayların bastırılması için bir kısım jandarma birlikleri ile 15. Tümen ve 5. Kafkas Tümenine bağlı alaylardan bazılarının bölgeye gönderilmesi, karargâh merkezi Amasya'da olacak Merkez Ordusunun kurulması, bölgede sıkıönetim ilanı, Amasya İstiklal Mahkemesinin kurulması, Rumların başka yerlere göç ettirilmesi, silahların toplanması, güvenlik amaçlı bir kısım teşkilatların kurulması ile Amasya ve Havalisi Kuva-yı Takibiye Kumandanlığı kurma çalışmalarıdır.

Amasya ve havalisinde Rumların terör eylemlerine karşı alınan önlemler ve uygulamalar sonunda eylemler önemli ölçüde azalmış, fakat tamamen bitirilememiştir. 1922 yılı sonlarında Batı cephesinde Yunanlılara karşı kazanılan başarılar sonunda Rumların bir kısmı, İstanbul'a bir kısmı da Yunanistan ve başka ülkelere göç etmişlerdir. Mesele, Lozan'da Türk ve Yunan tarafları ile 30 Ocak 1923'de yapılan "Türk ve Rum Nüfus Mübadelesine İlişkin Sözleşme ve Protokol'ün" imzalanması ile çözüme kavuşturulmuştur. Bu anlaşma ile Türkiye için Tarihi Pontus Meselesi sona ermiştir.

Millî Mücadele döneminde bir tarafta cephelerde Yunanlılarla savaşılması bir tarafta içerde Rumların bozguncu faaliyetleri ile uğraşmak zorunda kalınması mücadele sürecinin uzamasına yol açmıştır. Bu durum, o günlerin zor şartlarında eldeki askeri malzeme ve insan kaynağının seferber edilmesine yol açmıştır. İçerde belli bir gücün kullanılması zorunluluğu dışarda verilen mücadeleyi de etkilemiştir. Diğer taraftan bu olumsuzluklar, Türkiye'nin kurmaya çalıştığı yeni düzenin tesis edilmesini geciktirmiştir. En önemli sonuç, isyanların bastırılması ve bozguncu hareketlerin sona erdirilmesi TBMM'nin tanınmasına ve Anadolu'ya hâkim bir güç olduğunun anlaşılmasına vesile olmuştur. 
Millı̂ Mücadele Döneminde Amasya ve Havalisinde Pontus Terörüne Karşı Alınan Tedbirler

\section{Kaynakça}

\section{Arşiv Belgeleri}

Devlet Arşivleri Başkanlığı Cumhuriyet Arşivi, Kararlar Daire Başkanlığı, 030.18.1.1./2.38.2

Devlet Arşivleri Başkanlığı Cumhuriyet Arşivi, Kararlar Daire Başkanlığı, 030.18.1.1 /4.39. 9

\section{Süreli Yayınlar}

Düstur, Üçüncü tertip, C. 1.

TBMM Zabıt Ceridesi, C. 13, Devre 1, 98. içtima, (22.10.1337/1921)

TBMM Zabit Ceridesi, C. 1, Devre 1, 2. İçtima, (24.4.1336/1920)

TBMM Zabıt Ceridesi, C. 20, Devre 1, 44. İçtima, (18.5.1338/192)

TBMM Gizli Celse Zabıtları, C. 3, 51. Birleşim, Celse 3. (10. 6.1338/1922)

TBMM Gizli Celse Zabıtları, C. 2, 101.Birleşim, Celse 1. (29. 10.1337/1921)

TBMM Gizli Celse Zabıtları, C. 3, 81. Birleşim, Celse 2. (27. 7. 1338/1922)

\section{Kitaplar ve Makaleler}

ABDİZÂDE Hüseyin Hüsameddin Efendi, Amasya Tarihi (Yayına Hazırlayanlar: Mesut AydınGüler Aydın), Cilt 1, Amasya 2007.

ALAN, Gülbadi, Merzifon Amerikan Koleji ve Anadolu'daki Etkileri, Doktora Tezi, Erciyes Üniversitesi Sosyal Bilimler Enstitüsü, Kayseri 2002.

ALAN, Gülbadi, "Protestan Amerikan Misyonerleri, Anadolu'daki Rumlar ve Pontus Meselesi”, Erciyes Üniversitesi Sosyal Bilimler Enstitüsü Dergisi, Say1 10, 2001, s. 183-208.

ALAN, Gülbadi, “Amerikan Board Okullarında Yürütülen Misyonerlik Faaliyetleri” Journal of Islamic Research, 20 (4), 2007, s. 464-475.

ALKAN, A.Turan, İstiklal Mahkemeleri, Ağaç Yayıncılık, İstanbul 1993.

ARSLAN, Mukaddes, "İstiklal Mahkemeleri Belgelerinin Kamuoyuna Açılma Sürecinde T.B.M.M. Arşivi”, İstiklal Mahkemeleri, (İstiklâl Mahkemeleri Sempozyumu, 10-11 Aralık 2015-Adıyaman), Atatürk Araştırma Merkezi Yayınları, Ankara 2016, s. 87-108.

Arşiv Belgeleriyle Rum Faaliyetleri (1918-1922), Cilt I, Genel Kurmay Basımevi, Ankara 2009.

Atatürk'ün Tamim, Telgraf ve Beyannameleri, Atatürk Araştırma Merkezi, Ankara 1991.

AYBARS, Ergün, İstiklal Mahkemeleri 1920-1927, I. Bask1, İstanbul 1997.

BALCIOĞLU, Mustafa, "Birinci Dünya Savaşı Sırasında Karadeniz'de Rum Faaliyetleri ve Sivil Tepki”, OTAM, Say1 4, 1993, s. 91-97.

BALCIOĞLU, Mustafa, "Milli Mücadele Sırasında Merkezi Anadolu'da Asayişi Sağlamak İçin Oluşturulan Milis Kuruluşları", Atatürk Yolu Dergisi, Sayı 6, 1990, s. 261-274.

BALKAYA, İhsan Sabri, "Mütareke Dönemi Asayişin Üç Boyutu”, Atatürk Yolu Dergisi, S.41, May1s 2008, s. 17-34.

ÇETINNOĞLU, Sait-Dara Cibran, Pontus Sorunu, Ocak 2007. 
Turgut İleri

ÇETINNTAŞ, Cengiz, TBMM Tutanaklarında Pontus İsyanı ve Merkez Ordusu (1921-1923), 1. Bask1, 2018.

ÇEVIKK, Zeki-Filiz Özkan, "Pontus Terörünün I. Meclise Yansımaları (1920-1923)", Editör Osman Köse; Osmanlıdan Günümüze Eşklyalık ve Terör, Samsun İlk Adım Belediyesi Kültür Yayınları, Samsun 2017, s. 647-667.

ÇIÇEK, Rahmi, "Kastamonu İstiklâl Mahkemelerinin Bölgede Güvenlik ve Asayişin Sağlanmasındaki Rolü’ Ístiklal Mahkemeleri, (Ístiklâl Mahkemeleri Sempozyumu, 10-11 Aralık 2015-Adıyaman), Atatürk Araştırma Merkezi Yayınları, Ankara 2016, s. 209-240.

EVSILE, Mehmet, "Milli Mücadele Sirasında Cephe Gerisinde Güvenlik Problemleri”, Editör Osman Köse; Osmanlıdan Günümüze Eşkıyalık ve Terör, Samsun İlk Adım Belediyesi Kültür Yayınları, Samsun 2017, s. 491-504.

GEDİKLİ, Yusuf, Pontus Meselesi, İz Yayıncılık, İstanbul 2008.

GOLOĞLU, Mahmut, Anadolu'nun Milli Devleti Pontus, Ankara 1973.

GÖK, Salhadin, "Birinci Dönem İstiklal Mahkemelerinin TBMM'de Yansımaları" İstiklal Mahkemeleri Sempozyumu, 10-11 Aralık 2015, Adlyaman, Atatürk Araştırma Merkezi, Ankara 2016, s. 49-79.

GÖKBİLGİN, Tayyip, Milli Mücadele Başlarken, Türkiye İş bankası Yayınları, Ankara 1959.

GÜLMEZ, Nurettin, "Bodrum, Muğla ve Çevresinde Asayiş Durumu (1918-1920)”, Çağdaş Türkiye Tarihi Araştırmaları Dergisi, XVIII/Özel Sayı, 2018, s. 342-373.

HATIPOĞLU, M. Murat, "Gerçek ve Sanal Ortamlarda "Pontus Meselesi": Uluslararası İlişkilerde Asılsız İddialara ve Bilgi Kirliliğine Somut Bir Örnek”, Uluslararası Asya ve Kuzey Afrika Çalışmaları Kongresi, 38. ICANAS, Bildiriler, 10-15.09.2007, Cilt I, Ankara 2011, s. 831-847.

HAYDAROĞLU, İlknur Polat, Osmanlı İmparatorluğu'nda Yabancı Okullar, Kültür Bakanlığı Yayınları, İstanbul 1990.

İLERİ, Turgut, "Millî Mücadele Döneminde Amasya'da İstiklâl Mahkemesi Kurma Çalışmaları", Tarih Yolunda Bir Ömür, Ergün Öz Akçura Armağanı, Ed. Ahmet AksınYavuz Haykır-Filiz Yıldırım, Hiper yayın, C.II, I. Baskı, İstanbul 2019. s. 401-414.

Istiklal Mahkemeleri, (Kanun, Gerekçe ve Genel Kurul Tutanakları), C. 1, T.B.M.M. Basın, Yayın ve Halkla İlişkiler Başkanlığı Basımevi, Ankara 2015.

KARAL, Enver Ziya Karal, Osmanlı Tarihi, Cilt IV, Türk Tarih Kurumu Basımevi, Ankara 1983.

KAYMAKÇI, Salih Kaymakçı, “Amasya-Oluz Höyük’ te Mithradates VI Eupator Dönemi”, Uluslararası Amasya Sempozyumu Bildiriler Kitabı, Cilt 1, Amasya 2017, s. 285-290.

KESER, Ulvi, "Milli Mücadele Döneminde Ayrılıkçı Faaliyetlerde Kilisenin Rolü ve Hrisostomos-Hrisantos Girişimlerine Kesitsel Bir Bakış", Editör Osman Köse; Osmanlıdan Günümüze Eşkıyalık ve Terör, Samsun İlk Adım Belediyesi Kültür Yayınları, Samsun 2017, s. 579-614.

KILIÇ, Pelin İskender, "Samsun ve Çevresinde Pontus Çetelerinin Faaliyetleri ve Hükümetin Uygulamaları", Turkish Studies, Volume 6/2, 2011, s. 485-502. 
KURT, Yılmaz, Pontus Meselesi, TBMM Kültür, Sanat ve Yayın Kurulu Yayınları, Ankara 1995.

MAKSUDYAN, Nazan "Amerikan Kaynaklarında Merzifon Anadolu Koleji'nin Kisa Tarihçesi”, Kebikeç, Sayı 36, 2013, s. 131-153.

Nutuk 1919-1927, Atatürk Araştırma Merkezi, Ankara 1995.

OKUR, Mehmet, "Pontus Meselesinin Ortaya Çıkışı ve Karadeniz Bölgesinde Pontusçu Faaliyetler", Karadeniz Araştırmaları Dergisi, Sayı 14, (Yaz 2007), s. 1-28.

ÖZEL, Sabahattin, Milli Mücadele'de Trabzon, Ankara 1991.

PEHLIVANLI, Hamit, "Tarih Perspektifi İçerisinde Pontus Olayı: Yakın Tarihimize ve Günümüze Etkileri”, Atatürk Araştırma Merkezi Dergisi, Cilt X, Sayı 29, 1994, s. 357377.

SAYDAM, Abdullah, “Kurtuluş Savaşında Trabzon'a Yönelik Ermeni-Rum Tehdidi”, Atatürk Araştırma Merkezi Dergisi, Cilt 6, Sayı 17,1990, s. 421-434.

SÜRMELİ, Serpil, "Samsun ve Çevresinde Pontus Hareketi”, Atatürk Yolu Dergisi, Say1 19, 1997, s. 325-334.

UÇAROL, Rıfat, Siyasi Tarih, Filiz Kitabevi, İstanbul 1995.

YAZICI, Nuri, Milli Mücadelede (Canik Sancağında)Pontusçu Faaliyetler (1918-1922), Ankara 1989.

YERASIMOS, Stefanos, "Pontus Meselesi (1912-1913)", Toplum ve Bilim, 43-44, Güz-Kış 1989, s. 33-76.

ZELYUT, Rıza, İstiklal Harbi'nin Hukuk Cephesi İstiklal Mahkemeleri (Meclis Tutanakları), I. 